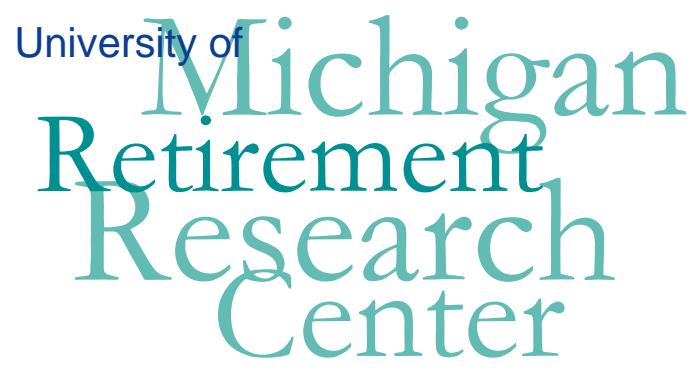

Working Paper WP 2007-155

The Effect of Retirement Incentives on Retirement Behavior: Evidence from the SelfEmployed in the United States and England Julie Zissimopoulos, Nicole Maestas and Lynn Karoly

\begin{tabular}{|l|l|l|l|l}
\hline $\mathrm{M}$ & $\mathrm{R}$ & Project \#: UM07-18 \\
\hline & $\mathrm{C}$ & $\mathrm{C}$
\end{tabular} 


\title{
The Effect of Retirement Incentives on Retirement Behavior: Evidence from the Self-Employed in the United States and England
}

\author{
Julie Zissimopoulos \\ RAND \\ Nicole Maestas \\ RAND \\ Lynn Karoly \\ RAND
}

September 2007

\author{
Michigan Retirement Research Center \\ University of Michigan \\ P.O. Box 1248 \\ Ann Arbor, MI 48104 \\ http://www.mrrc.isr.umich.edu/ \\ (734) 615-0422
}

\section{Acknowledgements}

This work was supported by a grant from the Social Security Administration through the Michigan Retirement Research Center (Grant \# 10-P-98362-5-04). The findings and conclusions expressed are solely those of the author and do not represent the views of the Social Security Administration, any agency of the Federal government, or the Michigan Retirement Research Center.

\section{Regents of the University of Michigan}

Julia Donovan Darrow, Ann Arbor; Laurence B. Deitch, Bingham Farms; Olivia P. Maynard, Goodrich; Rebecca McGowan, Ann Arbor; Andrea Fischer Newman, Ann Arbor; Andrew C. Richner, Grosse Pointe Park; S. Martin Taylor, Gross Pointe Farms; Katherine E. White, Ann Arbor; Mary Sue Coleman, ex officio 


\title{
The Effect of Retirement Incentives on Retirement Behavior: Evidence from the Self-Employed in the United States and England
}

\author{
Julie Zissimopoulos, Nicole Maestas and Lynn Karloy
}

\begin{abstract}
In this paper, we examine how public and private pension and health insurance systems affect the retirement transitions. In many countries, public and private pension eligibility, as well as access to health insurance varies between self-employed and wage and salary workers, and these differences are likely to cause differential retirement patterns both within and across countries. We use the variation in these institutional features within and across the United States and England to analyze retirement patterns. Based on longitudinal data from the Health and Retirement Study (HRS) in the United States and the English Longitudinal Survey of Ageing (ELSA) we find that the higher labor force exit rate of wage and salary workers compared to self-employed workers is due to defined benefit pension incentives created by the public and private pension systems. Higher rates of labor force exit at ages 55 and older in England compared to the United States are due in part to the availability of publicly provided health insurance.
\end{abstract}

\section{Authors’ Acknowledgements}

We gratefully acknowledge funding from the U.S. Social Security Administration (SSA) through the Michigan Retirement Research Consortium (MRRC). Additional funding was provided by a grant from the National Institute on Aging. The findings and conclusions expressed are solely those of the authors and do not represent the views of SSA, any agency of the Federal Government or MRRC. Please address correspondence to Julie Zissimopoulos, RAND, P.O. Box 2138, 1776 Main Street, Santa Monica, CA 90407; (telephone) 310-393-0411 x6638; (fax) 310-393-4818; (email) Julie_Zissimopoulos@rand.org. We would like to thank Beth Roth and Angela Miu for providing expert programming assistance. 


\section{INTRODUCTION}

According to data from the U. S. Bureau of Labor Statistics (BLS), 14.2 million U. S. workers, or 10.5 percent of the workforce, were self-employed in unincorporated or incorporated businesses in 2001. Since rates of self-employment rise with age, a disproportionate share of the self-employed is middle-aged or older workers. Some of these older workers have been self-employed for much or all of their working careers while others have made the transition to self-employment later in their careers, often as part of the transition to retirement. Similar patterns exist among older workers in England where approximately one quarter of workers over age 60 are self-employed. Selfemployment among older workers in both countries is likely to become more prevalent over time given the growing size of the older population and policy changes promoting work among older individuals.

Despite the prevalence of self-employment at older ages, few studies examine the labor force transition patterns of older self-employed workers. Although self-employed workers are from both the bottom and top of the wealth distribution, they on average, hold more wealth than wage and salary workers yet tend to retire later than their wage and salary counterparts. Understanding why self-employed workers are less likely to exit the labor force at older ages relative to their wage and salary counterparts may assist policy makers seeking to encourage later retirement ages. The retirement decisions of older workers have implications for the adequacy of national savings rates and the solvency of social insurance programs such as Social Security in the United States. Moreover, countries differ in their treatment of the self-employed in pension and health insurance systems, and this variation can assist in our understanding of how institutions affect the labor force participation decisions of older workers.

Table 1 shows self-employment rates by age among older workers for ten European countries, England, and the United States. The table reveals substantial heterogeneity in self-employment rates across countries, ranging from just eight percent of 50-55 year old workers in Denmark to 36 percent of such workers in Greece. The United States and England are in the middle of the range with 19 and 16 percent of 50-55 year old workers in self-employment, respectively. The table also illustrates how self- 
employment rates rise dramatically with age, more than doubling by ages 65 and older in virtually every country. For example, 26 percent of workers in Denmark are selfemployed by ages 65 and older, 62 percent are self-employed in Greece, 40 percent in England, and 37 percent in the United States.

While some of the rise in self-employment with age is due to later-life transitions into self-employment, most of it is due to differential retirement rates between the selfemployed and wage and salary workers. In many countries, public and private pension eligibility, as well as access to health insurance varies between self-employed and wage and salary workers, and these differences are likely to cause differential retirement patterns both within and across countries. By exploiting variation in these institutional features within and across countries, we can explore the effect of policy parameters that often cannot be studied in a single country.

In this paper, we examine how public and private pension and health insurance systems affect the retirement transitions of self-employed older workers compared to wage and salary workers. We focus our analysis on the United States and England as these are the only countries of those shown in Table 1 for which the necessary panel data are currently available. Specifically, we rely on longitudinal data from the Health and Retirement Study (HRS) in the United States and the English Longitudinal Survey of Ageing (ELSA). These data sources have the advantage of comparable demographic, economic, and labor market data on workers in the two countries.

We find that the higher labor force exit rate of wage and salary workers compared to self-employed workers is due to defined benefit pension incentives created by the public and private pension systems. Higher rates of labor force exit at ages 55 and older in England compared to the United States are due in part to the availability of publicly provided health insurance. These findings underscore the importance of institutional features of the labor market in influencing individual retirement decisions. They also suggest that in the United States, the availability of Medicare at age 65 limits the proportion of workers willing to work past 65 but that the movement of employers away from defined benefit pension plans is likely to encourage work at older ages. 


\section{PRIOR RESEARCH ON RETIREMENT AND SELF-EMPLOYMENT IN THE UNITED STATES AND ENGLAND}

A substantial literature in the United States focuses on the determinants of transitions to retirement (for reviews, see Hurd, 1990a and Lumsdaine and Mitchell, 1999). Much of this literature is motivated by the trend in the postwar period toward early retirement in the United States, attributed, in part or wholly to the increased generosity of Social Security, notably the windfall gains during the 1960s and 1970s (Costa, 1998; Hurd and Boskin, 1984; Ippolito, 1990). Recent evidence, however, indicates that labor force participation rates among older men have stabilized or even begun to increase (Quinn, 1999; Karoly and Panis, 2004). The timing of retirement is in part determined by the incentives embedded in the rules determining Social Security benefits, as well as employer-provided pension benefits (see Hurd, 1990b and Lumsdaine and Mitchell, 1999 for reviews and Anderson, Gustman and Steinmeier, 1999; Samwick, 1998). In the United Kingdom, Meghir and Whitehouse (1997) also found that financial incentives to retire are strongly predictive of actual retirement behavior. Likewise, other cross-national research published in a volume edited by Gruber and Wise (1999) notes that there is a strong negative correlation between labor force participation at older ages and the generosity of early retirement benefits. This study also shows that even with the limited number of observations available in cross-national studies, the effects of institutions and policies are important enough to generate convincing results.

The role of health status in affecting the timing of retirement has received extensive study, with most studies finding that workers in poor health are more likely to leave the labor force early (see the reviews by Sammartino, 1987, and Currie and Madrian, 1999). There is less consensus regarding the magnitude of the effect which can vary with the health measure used and estimation methods for addressing the potential endogeneity of health status and labor force decisions. A series of studies estimating both reduced form and structural models have also confirmed that health insurance, particularly the availability of employer-provided retiree health benefits, raises the likelihood of retirement although the magnitude of the effect ranges across studies (see the reviews by Currie and Madrian, 1999, and Gruber and Madrian, 2002). Wealth is also a potentially important determinant of retirement, and several recent studies have 
found positive effects of wealth shocks such as inheritances or the run-up in the stock market in the 1990s on actual and anticipated retirement (Holtz-Eakin, Joulfaian and Rosen, 1993; Hurd and Reti, 2001; Sevak, 2002). Other factors that affect retirement timing include retirement expectations (Hurd, 1999b), job characteristics (Hurd and McGarry, 1993), and mortality risk (Hurd, Smith and Zissimopoulos, 2003).

In studying the retirement process, researchers have generally not differentiated between retirement from the wage and salary sector versus self-employment. Exceptions to this include Fuchs (1982), Quinn (1999), Hochguertel (2005) Parker and Rougier (2007), and Zissimopoulos and Karoly (2007b). Fuchs (1982), using the United States Retirement History Survey (RHS), finds that the self-employed are more likely to continue to work - a differential of 8 percentage points - controlling for demographics, job characteristics, health status, pension coverage, and Social Security wealth. A similar result is reported by Quinn (1999) using the more recent HRS. The extent to which other determinants of retirement are different for the self-employed versus wage and salary workers remains largely unexplored. Hochguertel's (2005) cross-sectional analysis of preliminary data from the Survey of Health, Ageing and Retirement in Europe (SHARE) suggests that institutional differences in labor markets and social insurance programs play a role in differential retirement behavior from self-employment and wage and salary work. Parker and Rougier (2007) use data from the 1988/1989 and 1994 British Retirement Survey and find that while the 'long-term' self-employed retire later than wage and salary employees, this is not the case for workers who transition into selfemployment at later ages. This study is one of the first to analyze retirement behavior of self-employed workers in Britain but it is based on a small number of observations and an older birth cohort that retired more than a decade ago. Zissimopoulos and Karoly (2007) use seven waves of the HRS to examine the extent to which job characteristics influence the decision of self-employed workers to exit the labor force and find the long-term selfemployed and those with 6 or more employees are less likely to exit the labor force than the more recently self-employed and those with few or no employees. 


\section{INSTITUTIONAL DIFFERENCES RELEVANT FOR RETIREMENT BEHAVIOR IN THE UNITED STATES AND ENGLAND}

Our analysis of data from the HRS and ELSA allow us to exploit institutional variation across the United States and the United Kingdom. ${ }^{1}$ In this section, we review key differences in pension systems, disability insurance and other benefits, and health insurance - all features that are potentially relevant for understanding differences in retirement behavior differences by class of worker within and between the two countries.

\section{Pension Systems}

The United Kingdom's pension program is unusual in its mix of public and private provision, and in the opportunity for individuals to choose between these alternatives. The system is structured in two tiers. The first tier is provided publicly and consists of a flat contributory pension benefit, known as the basic state pension, which is augmented by a means-tested component. Because the benefit is unrelated to earnings, once contribution requirements are met, there is no further increase in pension entitlement from additional years of work or earnings growth. Benefits are available at the state pension ages of 60 for women and 65 for men, regardless of employment status. ${ }^{2}$ In the mid 1990s, the basic state pension paid only about 16 percent of average male earnings and, because it is has been growing more slowly than male earnings, the percent of income it replaces has declined over time (Blundell and Johnson, 1997).

The second tier, for which participation is mandatory for all employees with earnings above a certain floor, requires that individuals either belong to a second, public contributory program known as the State Earnings Related Pension Scheme (SERPS) or else join a private pension plan. ${ }^{3}$ The plan can be of the defined benefit (DB) or defined contribution (DC) type, and can be individually purchased or collectively provided (e.g., by the individual's employer). Moreover, individuals can switch between these types of

${ }^{1}$ While ELSA covers England only, we discuss institutional and policy differences between the United States and the entire United Kingdom. We note the extent to which there are differences between England and the rest of the United Kingdom in the institutional and policy differences we document.

2 The state pension age for women is scheduled to gradually increase to age 65 between 2010-2011 and 2020-2021.

${ }^{3}$ A gradual replacement of SERPS by the State Second Pension (SSP) began in 2002. Once fully phased in, the latter will effectively be a flat top-up to the first tier basic state pension, being more generous to low earners than SERPS. 
second tier arrangement during their working lifetime. Unlike the basic state pension, the level of benefits paid by SERPS, or its successor SSP, depends on the individual's earnings history, and thus may be affected by additional years of work. Like the basic state pension, there is no earnings test for SERPS or SSP. Membership in SERPS, for example, means that an individual can only receive benefits at the state pension age, whereas membership in a company-provided pension plan will typically allow retirement before the state pension age, quite often at age 60 . In contrast, a member of an individually-purchased defined contribution plan (known as a 'Personal Pension') can annuitize at any time between ages 50 and 75 .

The self-employed are entitled to the basic state pension as long as they have met the contribution requirements, but they are not eligible for SERPS or SSP. Since the selfemployed typically do not have the option of participating in an occupational pension, they must contribute to some form of Personal Pension. Although some may have SERPS entitlement or an occupational pension entitlement from previous wage and salary work, the long-term self-employed are much less likely to face significant work disincentives through the pension system.

In contrast to the United Kingdom, the pension system in the United States features a single public pension program, known as Social Security. Although a private pension system exists alongside the public system, individuals do not have the option of participating in one or the other. While the public part of the U.K. system has a single state pension age (which is currently different for men and women), the U.S. system permits claiming of benefits at both early and full retirement ages, which are the same for both men and women. Currently, the early retirement age is 62 and the full retirement age is gradually rising from 65 to 67 . The basic retirement benefit varies by work history and age at claiming, but has a progressive structure.

While most U.K. workers are required to participate in the second tier of pension provision through their employers or via Personal Pensions, there is no such requirement in the United States. In practice, about 44 percent of workers are covered by an employer-provided pension, a declining share of which are DB plans. Participation in personal savings vehicles such as Individual Retirement Accounts is not mandatory. Prior to 2000, U.S. Social Security benefits received at any age were subject to an 
earnings test, but since then the earnings test applies only to benefits received between age 62 and the full retirement age. At present, the benefits of early retirees are reduced by $\$ 1$ for every $\$ 2$ earned above the annual limit ( $\$ 11,280$ in 2002). This stands in contrast to the United Kingdom where the earnings test was abolished in 1989.

Unlike the United Kingdom, the self-employed in the United States are entitled to participate in the public pension system. Thus, the retirement incentives arising through the public system are the same for both classes of workers. Because wage and salary workers are more likely to participate in employer-provided pensions, they are more likely to face additional retirement incentives arising from DB pensions, which feature early retirement ages that typically precede the Social Security early retirement age, but this fraction is gradually declining as employers steadily replace their DB pensions with DC schemes, such as 401(k) plans. Self-employed workers in the United States whose businesses are not incorporated are not eligible to participate in 401(k) plans, but may contribute to a Self-Employment Plan IRA, which has significantly higher contribution limits than 401(k) plans.

\section{Disability Insurance and Other Benefits}

In the United Kingdom, disability benefits are paid to the long-term sick and disabled through a contributory program known as Incapacity Benefit. Historically, benefits were taken-up widely by older nonworkers, and reforms in 1995 were intended to significantly tighten eligibility (Blundell and Johnson, 1997). For example, as of 2001, the incapacity benefit is means tested against private pension benefits. In the United States, disability benefits are available through the Disability Insurance (DI) program if an individual has worked during five of the past ten years, or through the means-tested Supplemental Security Income (SSI) program if they do not qualify for DI. Although DI benefits are not means-tested against assets and non-labor income, benefits are subject to an earnings test, whereby recipients who earn more than an indexed earnings ceiling (\$740 per month in 2001) lose eligibility for continued benefits. DI benefits do not begin immediately following the onset of disability; the lengthy application process can be initiated only after a five-month waiting period. 
The presence of several other types of benefits that are explicitly targeted to and widely taken up by older individuals in the United Kingdom further distinguishes the two countries. Of special note is the U.K. mean-tested Income Support program, where beginning at age 60 , eligibility no longer depends on demonstrating that one is actively seeking work. Furthermore, Income Support for pensioners was expanded through the Minimum Income Guarantee program introduced in 1999. In addition, individuals become eligible for a variety of other benefits at age 60, some of which are means tested. Examples include a housing benefit, savings credit (for people with low assets), winter fuel payments (not means tested), and a tax credit to offset local tax bills. Although the United Kingdom does not officially designate an early retirement age, the availability of other benefits and many occupational pension benefits beginning at age 60 means that age 60 functions as a de facto early retirement age for men (Blundell and Johnson, 1997). In the United States, means-tested income support is also available to the elderly beginning at age 65 through the SSI program, provided Social Security benefits are low enough.

\section{Health Insurance}

The provision of health insurance differs dramatically between the United States and the United Kingdom. Whereas publicly provided universal health insurance is available at all ages in the United Kingdom, nearly universal health insurance coverage through the Medicare program in the United States begins at age 65. Generally, individuals are fully insured by Medicare if they or their spouse has worked and paid taxes into the system for at least ten years. Eligibility extends equally to wage and salary workers and the self-employed, although the self-employed pay twice the contribution rate since they are responsible for both the employer and employee shares. Health insurance for the non-elderly is not universal in the United States, but is largely provided by employers who purchase insurance through a group insurance market. Although retirement benefits are available from Social Security as early as age 62, Medicare benefits are not available until age 65 . For those without access to employer-based retiree health insurance, this can be a significant deterrent to early retirement. The selfemployed, who typically do not have access to the group insurance market, can purchase 
health insurance on the individual market, but they do not benefit from the price advantage conferred by group risk pooling. Consequently, the non-elderly self-employed are less likely to have health insurance coverage.

\section{Summary of Institutional Differences}

In sum, the typical wage and salary worker in the United Kingdom participates in some kind of DB scheme, either through the state or an employer and faces retirement incentives associated with key retirement ages. In contrast, the typical long-term selfemployed worker in the United Kingdom is enrolled in a DC scheme, with no such retirement incentives arising at key ages. Although they do participate in the first-tier of the public system, which does not allow benefit claiming until the state pension age, the benefit amount is unaffected by additional years of work and replaces a small portion of pre-retirement earnings. While the state pension age for men in the United Kingdom is 65 , the availability of other types of public benefits facilitates early retirement at age 60 . Because the self-employed face the same eligibility criteria for these other benefits as wage and salary workers, benefit availability is unlikely to have a differential effect on retirement patterns within the United Kingdom, but the availability of these benefits may serve to raise retirement rates relative to the United States.

In the United States, the differences in the retirement incentives faced by wage and salary workers and the self-employed are much less stark. Both classes of workers participate in a DB public pension system. Wage and salary workers are more likely to have an employer-provided DB plan as well, but participation in such plans is far from universal. As a class, the pension arrangements of wage and salary workers are becoming more and more similar to those of self-employed workers, as employers phase out DB plans in favor of DC plans.

The lack of universal health insurance coverage in the United States prior to age 65 suggests that health insurance arrangements are likely to play an important role in the United States, unlike the United Kingdom. Compared to the United Kingdom, job lock issues may be particularly important for older wage and salary workers who do not have access to retiree health insurance through their employer, causing them to delay retirement until they are at least within 18 months of turning 65 and thus eligible to 
continue their employer coverage until their $65^{\text {th }}$ birthday. Because the self-employed typically purchase insurance on the individual market as it is, their health insurance coverage does not explicitly depend on whether they continue working, although the relatively high cost of individual health insurance may effectively prevent retirement prior to Medicare eligibility.

On balance, the differing institutional arrangements in the United States and United Kingdom suggest that retirement rates might be higher in the United Kingdom, and in both countries, higher among wage and salary workers than among the selfemployed. We expect some systematic effect of key retirement ages, perhaps most strongly for wage and salary workers in the United Kingdom (because private and public eligibility ages tend to be coordinated), followed by wage and salary workers in the United States, and then the self-employed in the United States. Key retirement ages should affect the self-employed in the United Kingdom least of all, given their low likelihood of participating in any kind of DB pension, whether private or public, although their potential participation in other public benefit programs makes the effect of key retirement age on self-employed workers in the United Kingdom somewhat ambiguous.

\section{THE HRS AND ELSA DATA}

This research is based on two longitudinal surveys in the United States and England designed to examine changes in labor force status, income, wealth and health among older individuals. The HRS, first fielded in 1992, is a U.S. sample of approximately 7,600 households (12,654 individuals) with at least one person in the birth cohorts of 1931 through 1941 (about 51 to 61 years old at the wave 1 interview in 1992). This biennial survey was integrated in 1998 with another biennial survey: The Assets and Health Dynamics of the Oldest Old (AHEAD) survey including 6,052 households $(8,222$ individuals) with at least one person born in 1923 or earlier (age 70 or over as of the wave 1 interview in 1993). In 1998, the HRS (HRS98) was augmented with baseline interviews for a sample from the birth cohorts of 1924 through 1930 (the Children of the Depression Era or CODA cohort) and 1942 through 1947 (the War Babies cohort), and was representative of all cohorts born in 1947 or earlier. In 2004, the sample was further augmented with the 1948 to 1953 birth cohorts (the Early Baby Boom). Data from years, 
1992, 1993, 1994, 1995, 1996, 1998, 2000, 2002, 2004 are currently available, although this paper relies only on the 2002 and 2004 waves (comparable to the time period covered by ELSA).

The ELSA is modeled on the HRS and designed to facilitate cross-national analyses of aging by collecting comparable data on labor force transitions, health, wealth, and other demographic and job characteristics. The ELSA survey sample is drawn from respondents to the Health Survey for England (HSE). The HSE is a study conducted jointly by the Department of Epidemiology and Public Health, University College London, and the National Centre for Social Research, on behalf of the Department of Health. Approximately 12,000 respondents from three separate years of that survey (1998, 2000 and 2001) were recruited to provide a representative sample of the English population aged 50 or over at baseline. Because the ELSA sampling source is the HSE, baseline data on respondents' health have been collected and were supplemented by collection of economic data in the first wave of ELSA in 2002. The second wave of data collection took place in 2004 and both waves of data are publicly available and used in this analysis. All waves are conducted using face-to-face interviews.

The ELSA survey instrument has been constructed to be as comparable as possible to the HRS within the constraints of institutional differences between the countries. As a result, direct comparisons between the surveys are possible in many domains of economic and health measures. The analysis is conducted using weighted data to account for any bias due to non-random non-response in ELSA and in the HRS, in addition, to account for over-sampling of certain groups. HRS and ELSA include the following measures central to our research: workforce status, including whether the individual is self-employed or not; pensions from current and previous jobs and private pensions including plan details such as normal and early retirement ages; household wealth including information on assets and their values; and earnings. The surveys also provide other pertinent information for the study of self-employed older workers: demographic, health, and job characteristics. For married couples, the surveys collect these data on both individuals. The following discussion focuses on the measures most important to our study. Because of the similarity in survey design, we focus on a description of the HRS data, noting differences with ELSA when relevant. 


\section{Labor Force Status and Class of Worker}

In each wave, respondents are asked if he or she is currently working for pay (HRS) or did any paid work in the last month (ELSA). The transition from working for pay in one wave to not working for pay in the next is our outcome of interest. ${ }^{4}$ In terms of employment class, workers in each baseline interview are asked whether they are currently self-employed in their main job, and if so, how long they have been selfemployed (i.e., tenure on the current job), and whether they work with their spouse (HRS only) and/or other employees (HRS and ELSA). ${ }^{5}$ This information is updated at each subsequent interview wave. We use the employment history information in both surveys to further classify self-employed respondents according to whether they became selfemployed before or after age 50 .

\section{Household Wealth and Income}

HRS has a comprehensive set of questions to measure household wealth. Assets were separated into the following eleven categories: other real estate; vehicles; business equity; IRA or Keogh accounts; stocks or mutual funds; checking, savings or money market funds; CD's, government savings bonds or treasury bills; other bonds; other assets; and other debt. Housing equity is collected separately. HRS has pioneered methods such as unfolding brackets (Juster and Smith, 1997) to improve the quality of wealth measures in household surveys, methods that have been adopted in ELSA. As a result of these data quality efforts, HRS is now widely regarded as providing the best measurement of wealth in household surveys that lack a high-income over-sample. In collecting income data, similar methods are used. Household income in both surveys includes income from (self and spouse) labor earnings, capital, pensions, public programs and other sources.

4 There are other data available to examine labor force transitions between waves including selfreports of retirement and labor force status. These measures, however, tend to be more subjective and may have different meanings across countries. Future work will examine changes in "usual hours of work per week," which may be considered objective and commonly defined across countries.

${ }^{5}$ We explored other definitions of self-employment including self-employment in a second job, as well as part-time and full-time self-employment, as defined by report of self-employment income and as defined by reports of business ownership although results from this analysis are not included in this paper. 


\section{Pensions}

One focus of this study is how public and private pensions affect labor force transitions of older self-employed and wage workers. The surveys ask respondents if they have employer and/or private pensions, type of pension, normal and early retirement ages associated with these pensions. In the HRS and ELSA, employer pensions are reported as being of a type where benefits are tied to age or years of service as is typical of DB plans or as being a DC type of plan. In ELSA, respondents also report whether they participate in other private pensions such as private personal pensions, group personal pensions, stakeholder pensions, S226 plans (self-employed personal pension), retirement annuity pensions, and other retirement savings. For comparability of pensions in the United States and England, we classify all DC pensions in HRS and ELSA and the other private pensions reported in ELSA as DC. In our analysis, we use pension eligibility ages to model DB pension incentives. Although DB pension wealth can be constructed

for the HRS sample using restricted Social Security earnings records, no such files are yet available for ELSA.

\section{Health Insurance}

In prior research, as noted above, access to health insurance has been shown to be correlated with self-employment rates in the United States. In the United States, there is no universal coverage through the public system with the exception of individuals age 65 and older through Medicare. In the HRS, respondents are asked if they are covered by health insurance and type (employer, spouse's employer, government or other) and if this health insurance covers retirees, up to age 65. There is no parallel questioning in ELSA because the public health care system is universal.

\section{DESCRIPTIVE ANALYSIS OF SELF-EMPLOYMENT AND EMPLOYMENT TRANSITIONS}

We begin our analysis of the HRS and ELSA data by tabulating, for the two countries, the characteristics of the self-employed versus their wage and salary counterparts. For this analysis, we restrict the 2002 cross-sectional samples in the HRS and ELSA to workers who are ages 55 to 70 so we analyze the same age cohort in the 
two countries. We conclude this section with a descriptive analysis of employment transitions between the 2002 and 2004 HRS and ELSA survey waves.

\section{Characteristics of the Self-Employed}

Table 2 reports self-employment rates for workers age 55 to 70 in 2002 in the United States and England, in total and separately for males and females. Overall 22 percent of older U.S. workers are self-employed compared with 20 percent in England. In both countries, the self-employment rate is higher for men than for women, but the female-male gap in the relative odds of being self-employed is smaller for U.S. women compared with their English counterparts.

Table 2 also shows differences in the composition of the self-employed for the two countries, in total and by gender, where the self-employed are classified by age of self-employment and by the nature of self-employment. In the United States, a higher share of the self-employed is self-employed before age 50 (as opposed to at or after age 50) compared with workers in England (68 versus 57 percent). Men are more likely to be longer-term self-employed in both countries, but as with self-employment rates overall, the male-female gap in age of self-employment is smaller in the United States than it is in England. The composition of the self-employed, defined in terms of the presence of employees, is considerably different in the United States and England. Whereas 61 percent of the U.S. self-employed are in businesses with employees (other than their spouse), that figure is just 20 percent in England. ${ }^{6}$ Self-employed men are more likely to have employees in both countries, but the female-male gap is higher in the United States, in part because the fraction with employees is so much lower in England, for both men and women.

To explore differences in the characteristics of self-employed workers, Table 3 provides tabulations of several key demographic and economic variables for the HRS and ELSA samples for wage and salary workers versus the self-employed. The characteristics include the proportion male, married, foreign born, and working part time;

6 The percentage of self-employed workers in England with employees among the non-missing observations is approximately $14 \%$ lower than that reported in the U.K. census for England and Wales. However, respondents in the unclassified group are likely to have employees because their income and wealth are on average similar to self-employed respondents with employees. 
and the distribution by age group, self-reported health status, and quartiles of income and wealth (where the quartiles are defined separately for the entire HRS and ELSA samples). A comparison of the two countries overall (tabulations not shown) indicates that, compared with workers in England ages 55 to 70, workers in the United States in the same age range are less likely to be male, married, or working part time. They are somewhat more likely to be foreign born and considerably more likely to self-report that they are in "excellent" health. They are on average older and drawn from families with higher income but not higher wealth.

For both the United States and England, compared with wage and salary workers, the self-employed are more likely to be male and distributed toward older ages. While the U.S. self-employed are somewhat more likely to be married and foreign born compared with their wage and salary counterparts, the reverse is true for England. A higher fraction of U.S. self-employed workers self-report that their health is "excellent" compared with U.S. wage and salary workers, yet self-reported health status varies little between self-employed and wage and salary workers in England. U.S. self-employed workers are also considerably more likely to work part time compared with wage and salary workers (32 versus 17 percent), whereas the share working part time is identical (35 percent) for the two groups of workers in England and approximately equal to that of self-employed workers in the United States. The higher percentage of part-time wage workers in England compared to the United States is largely driven by high numbers of part-time female workers in England. Indeed, among males, the percentage of part-time wage and salary workers is low in both countries (12 percent in the United States and 16 percent in England). Finally, the self-employed in the United States are distributed toward the higher end of the income and wealth distribution compared with wage and salary workers. In England, this relationship also holds for the wealth of the selfemployed but not their income.

Relevant for retirement decisions in the U.S. is access to health insurance before age 65 when Medicare coverage begins. Among wage and salary workers under the age of 65, 60 percent have employer provided health insurance, another 16 percent have employer provided insurance with retiree benefits until age 65, and 26 percent have insurance provided through a spouse's employer or some other source (including public 
sources) with no retiree benefits and 6 percent have none of the above (Table 4). Among self-employed workers under the age of 65, fewer have these benefits: 38 percent have insurance through their work, only two percent also have retiree benefits, and 50 percent have insurance through another source including one's spouse and publicly provided sources and 15 percent have none of these sources (Table 4). ${ }^{7}$

Given the institutional differences between the United States and England, we might expect differences in access to private pension coverage in the two countries, as well as variation in the type of pension coverage and the associated behavioral incentives. Table 5 shows the pension coverage rate on the current job for wage and salary and selfemployed workers in the two countries, as well as for all workers. ${ }^{8}$ Overall, the pension coverage rate is slightly higher for England compared with the United States: 56 versus 52 percent. The contrast is much sharper, however, by class of worker. While 39 percent of the self-employed in England are covered by a pension on the current job, that rate is just 12 percent for the self-employed in the United States. In England, 96 percent of the self-employed with a pension report that it is a DC plan. In the United States, of the 12 percent of self-employed workers with a pension, 64 percent have a DC plan.

Figures 1 and 2 illustrate the variation across countries for all workers, and separately for workers by employment class, in the normal retirement age (NRA) and early retirement age (ERA) associated with their employment-based pension plan. Nearly half of wage and salary workers in England face an NRA of 65, while the NRA is 60 for nearly all other workers (Figure 1). In contrast, the NRA for U.S. workers is much less concentrated. Modal ages in descending frequency are 65, 62 and 55 with most of the remaining portion distributed between the age of 56 and 59. Variation is evident as well in the ERA as shown in Figure 2. Again, most English workers are concentrated in a few ages: 60,55 and 50. Modal points in the ERA distribution for U.S. workers include ages 55 and 62.

\footnotetext{
${ }^{7}$ The percentages add to slightly more than 100 because the types are not mutually exclusive.

8 The pension plan variables are defined for the first pension described by the respondent.
} 


\section{Labor Force Exits}

We use the longitudinal aspect of the HRS and ELSA data to analyze exits from the labor force by class of worker that occur between the 2002 and 2004 survey waves.

Figure 3 displays the age pattern of these transitions for workers in the United States and England defined by employment class at time $t$ (i.e., 2002). The age categories, defined as of time $t+2$ (i.e., 2004), are grouped into two-year intervals (with the exception of age 64) to reduce some of the noise in the age pattern because of small cell sizes in single-year age groups. As seen in Figure 3, the likelihood of moving to retirement generally increases with age in each country for both wage and salary and selfemployed workers. In England (lines plotted with solid lines and open symbols), the transition rates are higher at each age for wage and salary workers compared with their U.S. counterparts, and, in most cases, the transition rates are higher at each age for the self-employed too. For both countries, the transition rates are higher (or the same in the case of the United States) at each age for wage and salary workers compared with the self-employed. The impact of age of eligibility for public benefits is evident in the mean transition rates. In the U.S., the likelihood of exiting the labor force for both wage and salary and self-employed workers rises by 7 percentage points if they reach age 62 between waves. If they reach age 65 between waves, exits rise by 10 percentage points for wage and salary workers but there is no increase for self-employed workers. This suggests that the age 65 incentives are much stronger for wage and salary workers than self-employed workers in the U.S., consistent with the presence of health-insurance related job lock for the majority (60 percent, Table 4 ) of wage and salary workers. ${ }^{9}$ In England, we expect the incentives to retire at key ages to be much stronger for wage and salary workers than for self-employed workers compared to the U.S. Indeed, we find that among workers reaching the key ages of 60 and 65 in England between waves, wage and salary workers are much more likely to exit than self-employed workers (11 versus 6 percentage points at age 60 and 19 versus 12 percentage points at age 65).

\footnotetext{
${ }^{9}$ Public and private age- 65 pension incentives are unlikely to be the explanation since both wage and salary and self-employed workers in the United States face the same set of incentives through the Social Security system, and only 6 percent of all wage and salary workers have a private pension in which age 65 is a key retirement age.
} 


\section{REGRESSION ANALYSIS OF RETIREMENT TRANSITIONS}

In this section, we estimate a retirement transition model for England and the United States. We begin by describing the model specification, identification assumptions, and continue with a discussion of our findings and associated simulations.

\section{Model Specification}

We use a linear probability model to estimate the probability of exiting the labor force (defined as not working for pay) by 2004 conditional upon working for pay in 2002 . We estimate a pooled model for all workers, but fully interact all covariates with indicators for country and class of worker (i.e., self-employed in the United States, wage and salary in the United States, self-employed in England, wage and salary in England). Our results may be interpreted as causal only if two identifying assumptions hold: 1) workers in the United States and England have similar underlying preferences for work and leisure (although the institutions constraining their decisions may vary), and 2) the self-employment (wage and salary) decision is not jointly chosen with anticipated retirement age based on age of eligibility for retirement benefits. The first assumption is not testable; however, it often implicitly underlies cross-national analyses of this type (e.g., Gruber and Wise, 1999). The latter assumption is more likely to hold for individuals who became self-employed at relatively younger ages, as a substantial literature suggests that most retirement planning occurs after age $50 .{ }^{10}$ We assess the plausibility of this assumption by estimating our transition models both for the full sample of self-employed respondents, and also for the subsample who became selfemployed before age 50, and for whom the self-employment decision may be more plausibly predetermined.

We model institutional incentives using the age-eligibility structure of private and public benefits. Although this approach uses less variation than if we had pension wealth, our flexible age structure picks up the nonlinearities in pension wealth that likely affect behavior without relying on less desirable variation in pension wealth owing to past earnings. Our focus is on how age eligibility for public benefits affects the probability of

\footnotetext{
${ }^{10}$ For example, in the HRS, Lusardi (2003) finds that about half of non-retired respondents 51 and older have thought little or not at all about retirement.
} 
exiting the labor force. We use age measured in $2004(t+2)$ to determine benefit eligibility (Age04). To allow for a flexible age structure and for slope and intercept shifts at the ages of early and standard eligibility for public pensions we include in the model a quadratic in age in 2004, an indicator of eligibility for early public pension benefits (Age04_PEA), an indicator of eligibility for standard (normal) public pension benefits (Age04_PNA) and interactions of these indicator variables with the quadratic in age. For example, in the United States, the age of eligibility for early and reduced public old age pension benefits is 62 thus Age04_PEA is equal to one for workers who are 62, 63 or 64 in 2004. Similarly, Age04_PNA is equal to one for workers who are 65 and older. Although the age of eligibility for full benefits ranges between 65-67, depending on birth year, no worker in our sample eligible for full benefits at age 66 or older reaches those ages by $2004 .{ }^{11}$ In England, we follow the conventional wisdom that for all practical purposes, the age of eligibility for early old age public pension benefits is age 60 for both female and male workers and the standard age of eligibility is 65 for male workers. ${ }^{12}$

We model the age structure of incentives arising through private pensions by defining private pension eligibility ages relative to the public eligibility ages (PEA or PNA). Specifically, we include indictor variables for if the worker has a defined benefit or defined contribution private or employer pension. For those with defined benefit plans, workers are grouped into mutually exclusive categories by whether the early and normal retirement ages (ERA and NRA, respectively) for the plan coincide with the eligibility ages for public pension benefits. For example, in the United States a worker with a defined benefit plan is categorized in one of 6 ways: early and normal retirement ages are less than age 62 (ERA \& NRA $<$ PEA); early retirement age is less than age 62 and normal age is 62 to 64 (ERA $<$ PEA, NRA $\geq$ PEA \& $<$ PNA); early retirement age is less than age 62 and normal age is 65 or older ( $\mathrm{ERA}<\mathrm{PEA}, \mathrm{NRA} \geq \mathrm{PNA}$ ); early retirement age is 62 to 64 and normal age is 62 to 64 (ERA \& NRA $\geq P E A$, ERA \& NRA $<\mathrm{PNA}$ ); early retirement age is $62-64$ and normal age is 65 or older (ERA $\geq$ PEA \& $<$ PNA, $\mathrm{NRA} \geq \mathrm{PNA}$; early retirement age and normal retirement age are both at 65 or older (ERA

\footnotetext{
11 The maximum full retirement age faced by respondents in our sample (b. 1932-1947) is 66 although no one in the cohort that is entitled to benefits at age 66 actually becomes 66 from 2002 to 2004 .

12 As described earlier, age 60 is not an official age for early benefits for male workers but in practice, there are many paths for early retirement through the public system at age 60 .
} 
$\& N R A \geq P N A$ ). Four additional categories are generated for those with missing data on the ERA or NRA for a total of 10 mutually exclusive and exhaustive categories. For male English workers with a defined benefit plan, these categories are less than age 60, 60 to 64 and 65 and older, and less than age 60 and 60 and older for female workers, corresponding to the age of public benefit receipt in England. Finally, these categorical indicators are interacted with the indicators of whether the worker is currently eligible for early public benefits (Age04_PEA) and for standard public benefits (Age04_PNA).

Another important benefit that becomes available at age 65 in the United States is health insurance coverage through the Medicare program. This eligibility may be particularly important for self-employed workers who may delay retirement until they have access to this benefit. In the model we include indicator variables for four types of health insurance at time $t$ : employer provided without retiree benefits, employer provided with retiree benefits, benefits through a spouse, and other insurance. We interact these insurance types with an indicator for Medicare eligibility at $t+2$; thus before age 65 the employer insurance categories refer to primary coverage, but after 65 they may refer to either primary or secondary coverage. ${ }^{13}$ To identify the effect of health insurance on retirement behavior, we assume that employment decisions in the United States are not made on the basis of whether or not an employer offers retiree health insurance.

Finally, we control for many other observable differences between workers in the U.S and England and between classes of worker (self-employed or wage and salary) that prior research has found and theory has indicated affect the likelihood of exiting the labor force: sex, marital status, self-reported health status, financial and housing wealth and total household income. Wealth and income are entered as interacted quartiles, with the second and third quartiles combined, and the quartile definitions are country specific.

\section{Model-based Age-specific Exit Rates}

The results of our full model are shown in Table 6. Owing to the large number of interaction terms, individual coefficients are difficult to interpret; therefore we illustrate

13 If an employer with 20 or more employees provides health insurance coverage to regular employees, then the employer is primary payer for regular employees age 65 and older and Medicare is secondary payer. If an employer does not offer coverage to regular employees, has fewer than 20 
our key results by showing how variation in pensions and health insurance arrangements (in the U.S.) affect the age profiles in labor force exit rates.

Figure 4 shows the predicted percentage of workers from England and the United States exiting the labor force from ages 55 to 70 based on our model, letting the indicators for early and standard eligibility take on the value of one at the appropriate ages, and holding all other covariates at their mean values. Variation in eligibility for public pensions alone generates age profiles in predicted transition rates that capture several notable features of the data. Consistent with observed exit rates, the model predicts higher exit rates for wage and salary workers than for self-employed workers in both countries. We expect that in England, the self-employed would be less responsive to the entitlement ages of 60 and 65 than wage and salary workers because they are not eligible for $2^{\text {nd }}$ tier public benefits and the replacement rate for $1^{\text {st }}$ tier benefits is small. Recall that in both the $1^{\text {st }}$ tier and the public portion of the $2^{\text {nd }}$ tier, eligibility ages are 60 for women and 65 for men, but that age 60 is treated as a de facto early retirement age for men. Furthermore, wage and salary workers who opt out of second tier public provision often have employer provided DB plans with early and normal retirement ages at 60 and 65. The model predicts that the exit rate for wage and salary workers in England increases dramatically from 16.3 percent at age 55 to 25.8 at age 59 . The exit rates increase by nearly 5 percentage points from age 59 to age 60 . In contrast, the predicted percentage of self-employed workers exiting the labor force in England is fairly constant from ages 55 to 59 , increasing from 19.7 to just 20.4 and increasing 3 percentage points from ages 59 to 60 . Exit rates increase 18 percentage points from age 64 to the standard retirement age of 65 for wage and salary workers and 14 percentage points for selfemployed workers. This latter effect is somewhat surprising, since self-employed workers in England cannot participate in the public DB system, and do not have private DB plans. Previewing results presented later, this spike is primarily driven by more recently self-employed workers who have potentially spent many years participating in the $2^{\text {nd }}$ tier public DB system, SERPS, and who consequently may be eligible to claim significant pension benefits at age 65. Comparing the model's predicted exit rates with

employees, or the individual is not classified as a regular employee, then Medicare is the primary payer (Centers for Medicare and Medicaid Services, 2005). 
observed exit rates we find that controlling for observable characteristics decreases some of the difference in exit rates at key ages between the classes of workers in England but substantial differences remain. Indeed, likelihood ratio tests reject the null-hypothesis that the coefficients on the standard age of eligibility are zero for wage and salary workers but cannot reject the null for self-employed workers in England. The null is rejected for all workers with respect to the coefficients on eligibility for early benefits.

In the United States, self-employed and wage and salary workers are part of the same pension system unlike in England where the self-employed are not part of the $2^{\text {nd }}$ tier of the system. In the United States, however, for most respondents in our sample the standard eligibility age for pension benefits coincides with the age for public coverage of health insurance through Medicare. This may be a particularly important benefit for selfemployed workers who do not have access to retiree health insurance benefits through an employer before the age of 65. As described above, we include an interaction with eligibility for age-65 Medicare benefits in $2004(t+2)$ and type (if any) of health insurance benefits in 2002. For example, workers without health insurance benefits will not have any particular incentive to wait until age 65 to retire relative to those with health insurance but no retiree benefits.

As seen in Figure 4, the predicted age-pattern of exits from the labor force is similar for both classes of workers in the U.S. although at all ages, wage and salary workers exit the labor force at higher rates than self-employed workers. The predicted percentage of workers exiting the labor force rises slowly for wage and salary workers, from 13.1 percent at age 55 to 19.7 percent at age 61 , and then increases 4.3 percentage points at age 62 . The percentage of self-employed workers exiting the labor force rises from 8.6 percent at age 55 to 18.9 percent at age 61 and increases by only 1 percentage point at age 62 to 20.1. For wage and salary workers in the U.S. the percentage of workers exiting the labor force increases by 17 percentage points between age 64 and 65 but less than one-half percentage point for self-employed workers. Compared to the observed rates of exit, controlling for observable differences between self-employed and wage and salary workers increases exit rates between the classes at age 62 and the 'raw' differences at age 65 remain. Likelihood ratio tests reject the null-hypothesis that the 
coefficients on the standard age of eligibility are zero for wage and salary workers but not for self-employed workers.

As noted earlier, the second identifying assumption is more likely to hold for the long-term self-employed than for all self-employed; therefore, we also estimate the model using the long-term self-employed (those self-employed before age 50), rather than all self-employed. Table 7 shows the predicted probability of exiting the labor force at each age for long-term self-employed workers in the United States and England along with the results for wage and salary workers (from Figure 4) with all covariates for both samples held at their mean values. At nearly all ages, exit rates are lower for the long-term selfemployed than for all self-employed, but the rate of change in the exit rates is similar at the early eligibility ages in both countries, and also at the standard eligibility ages in the U.S. While the age 61 to 62 increase in exits appears more pronounced for the long-term self-employed compared to all self-employed workers in the U.S., the effect of early eligibility is not statistically different than zero for these long-term workers- the same result as for all workers.

Interestingly, the effect of crossing the standard eligibility age (age 65) is substantially smaller for long-term self-employed workers in England which is to be expected given the lack of financial incentive provided by the public system for selfemployed workers, who are not eligible for second tier benefits, and who are unlikely to also have a prior DB plan through an employer. Thus it appears that those workers who became self-employed after age 50, who may have second tier benefits from prior wage and salary work and perhaps a DB pension from a prior employer, primarily drive the observed spike at age 65 for self-employed workers in England. Although the jump is greatly diminished, it does not vanish entirely, which in the absence of an earnings test associated with claiming of public benefits suggests the presence of liquidity constraints or social norms affecting all workers. In sum, although the age specific labor force exit patterns are somewhat different for the long-term self-employed compared to all selfemployed workers, we find, as we did in models including all self-employed workers, that the increase in retirement at the standard age of eligibility is larger for wage and salary workers and statistically different than zero only for wage and salary workers. 
Our next set of analyses examines the extent to which pension systems and health insurance can explain the age specific patterns. Previewing the next sets of results, the patterns are consistent with a hypothesis that self-employed workers' exit rates reflect their relatively unconstrained choices, or non-age specific incentives relative to wage and salary workers.

\section{The Effect of Health Insurance}

Access to non-employer provided health insurance benefits (or retiree benefits for wage workers) in the United States increases the percentage of workers exiting the labor force at all ages. We test for the joint-significance of the pre- 65 health insurance coefficients in Table 6 and find they are jointly significant for self-employed workers but not wage and salary workers. Figure 5 shows the predicted exit rates if all U.S. workers had access to health insurance prior to age 65 through a spouse, other non-employer insurance, or retiree benefits, with all other characteristics held at their mean and indicators for eligibility for standard and early public benefits taking the value of one at the appropriate age. Under the scenario that all U.S. workers have access to nonemployment related health insurance, pre-65 exit rates rise substantially, and the gap in exit rates between the self-employed and wage and salary workers virtually disappears. For self-employed workers, exit rates prior to age 65 rise by 8 percentage points and at age 65 and older, by 14 percent. For wage and salary workers, exit rates rise by 6 percentage points and 3 percentage points below and above age 65, respectively. This pattern suggests that not only is job lock an important phenomenon for U.S. wage and salary workers, but that it is perhaps even more important for self-employed workers, albeit through a different mechanism. Whereas wage and salary workers may need to keep working in order to maintain their access to heavily subsidized coverage, the selfemployed may need to work in order to afford the expense of individually-purchased health insurance or self-insurance. It is somewhat surprising that after age 65 , exit rates for both types of workers rise, and relatively more so for the self-employed. After 65, virtually all workers have access to Medicare, thus the simulation depicted in the graph refers to the addition of supplemental health insurance coverage for all workers, not primary coverage. While the rise in exit rates suggests that out-of-pocket medical 
expenditure risk is important, it is not clear why it would be relatively more important for the self-employed than for wage and salary workers. One hypothesis is that the removal of an important background risk would have a stronger impact on the self-employed because they are likely exposed to greater financial risk than wage workers.

Access to non-employer provided health insurance explains some of the difference in exit rates between self-employed workers in the U.S. and England. For selfemployed workers with access to health insurance through a spouse or other nonemployment related access, the predicted difference in exit rates at ages less than 62 falls from 8-11 percentage points to less than 4 percentage points. When we constrain the sample of self-employed workers in both countries to those who became self-employed before age 50, we find there is no difference in exit rates at age 65 and older among the self-employed in the U.S. and England (Table 8). Prior to 65, however, predicted exit rates for the long-term self-employed in the U.S. are substantially higher than those of the long-term self-employed in England.

\section{The Effect of Private Personal and Employer Provided Pensions}

Private pensions, particularly those that are defined benefit, are likely to influence the age at which a worker chooses to retire. As Figure 1 revealed, the normal retirement age for these plans more often than not, coincides with the ages of eligibility for public benefits thereby strengthening the incentive to retire at the key public benefit ages. In contrast, defined contribution plans are characterized by a lack of incentive to retire at particular ages. Approximately 64 percent of all wage and salary workers in the United States have a pension and among those with a pension, 62 percent have the defined benefit type. In England, 61 percent have a pension and among those with a pension, 49

percent have a defined benefit type of plan. In contrast, almost no self-employed workers have defined benefit pension plans through a current job. In England, however, 39 percent of all self-employed workers have a defined contribution plan, while in the United States only 12 percent of self-employed workers have a private pension plan. We use this variation between self-employed and wage and salary workers and workers in the United States and England to examine the extent to which eligibility for early and 
standard private pension benefits affects a worker's decision to exit the labor force in the United States and England.

As described earlier, our specification for pensions is quite detailed, including an indicator for having a DC pension, 10 indicators for type of DB pension (6 indicators defined according to how the early and standard eligibility ages relate to the public eligibility ages, plus an additional 4 for missing values), and interactions between the 10 DB types and age. Table 6 shows that for self-employed workers in both countries, having a DC pension is negatively associated with exiting the labor force relative to having no pension. The same is true for wage and salary workers in both countries. The effect of DB pensions, however, depends on the eligibility ages for early and standard benefits and the age of the worker. For wage and salary workers in England, the effect of having a pension is substantially larger than for wage and salary workers in the United States. To assist in interpreting the level effect of private pensions on exit rates in the United States and England and by class of worker we consider two types of pension arrangements and graph the predicted percentage of workers exiting the labor force under each scenario. In the first, wage and salary workers in both countries have only DC pensions (Figure 6). In the second, wage and salary workers in both countries have DB pension benefits with ages of eligibility for early and standard retirement benefits that correspond with the ages of eligibility in the public system and for self-employed workers, retirement probabilities are held at the mean values (Figure 7). For example, in the United States, we graph predicted exit rates for wage and salary workers who have a DB pension plan with early benefits at age 62 and standard benefits at age 65 . All other characteristics are held at their mean values and indicators for standard and early public benefits take the value of one at the appropriate age.

Under the scenario such that wage workers in both countries have only DC pensions (Figure 6), in the United States, wage workers decrease their rate of exit from the labor force by 5 percentage points at ages less than 65 and 10 percentage points at ages 65 and older, thereby narrowing the difference in exit rates between self-employed and wage and salary workers. In England, assuming wage workers have a DC private pension plan decreases exit rates at each age by just under 11 percentage points bringing the rates in line with those of the self-employed at ages 60 and older. 
Under the scenario such that the DC pension indicator for self-employed workers is held at its mean value and all wage and salary workers have DB private pension benefits with coordinated retirement ages, we find a very large effect on exits from the labor force at the early and standard retirement age (Figure 7). This large increase in the percentage of wage and salary workers exiting the labor force at these key ages dramatically increases the difference in exit rates between the two classes of workers in both countries and closes the gap in exit rates of wage and salary workers in the United States and England at ages 62 and 65.

Together, Figures 6 and 7 suggest an important role for private pension arrangements in driving the within and across country differences in exit rates. The change in exit rates across these two extremes - all wage workers with DB coverage v. all wage workers with DC coverage-illustrate the potential long-term effect on exit rates as employers continue their steady replacement of DB plans with DC plans.

\section{CONCLUSIONS}

Retirement rates are higher in England than in the United States and also higher among wage and salary workers than among the self-employed in both countries. One plausible explanation for these differences is the varying age specific institutional arrangements in the United States and United Kingdom that differentially impact workers of different employment classes. In the United States, we find that health insurance coverage is important for understanding differences in the probability a self-employed worker and a wage and salary worker exits the labor force. We find that before age 65 , having access to health insurance through a spouse or having retiree benefits, which few self-employed workers have, increase the probability of exiting the labor force and if applied to self-employed workers, their rates of exit would be at or above those of wage and salary workers and similar to those of self-employed workers in England prior to age 65. Indeed, access to non-employment linked health insurance increases exit rates of U.S. self-employed workers by 8 percentage points at ages less than 65 and thereby decreases the difference in exit rates between self-employed workers in the U.S. and England from between 9 and 18 percentage points (depending on age) to less than 4 
percentage points at all ages less than 65. Among long-term self-employed workers, the gap is completely eliminated.

Being eligible for a private, defined benefit pension plan is almost exclusively a characteristic of wage and salary workers in both countries, and often these plans have eligibility ages tied to age of eligibility for public benefits. Access to DB plans and the age structure of their benefits serve to exacerbate the inter-country difference in labor force exit rates of self-employed and wage and salary workers. Indeed, in both countries, predicted exit rates by class of worker are almost identical if all workers are constrained to DC pensions only (no DB pensions). The persistent increase in exit rates at age 65 in England for workers with only DC pension plans suggests the existence of either liquidity constraints or social norms. That is, because there is no earnings test in the public DB pension system, we would not expect a spike at age 65 for workers without private DB pension plans with a normal retirement age at 65 .

Examining the change in age-specific labor force exit rates of older self-employed workers in the U.S and England, who face no employer imposed constraints, and comparing them to their wage and salary counterparts as well as to each other serves to illustrate the importance of access to health insurance and age-eligibility requirements of pension systems in influencing an individual's decision of when to retire. The results suggest that in the United States, the availability of Medicare at age 65 limits the proportion of workers willing to work past 65 but that the movement of employers away from defined benefit pension plans is likely to encourage work at older ages. 


\section{REFERENCES}

Anderson, A. Gustman and T. Steinmeier, "Trends in Males Labor Force Participation and Retirement: Some Evidence on the Role of Pensions and Social Security in the 1970's and 1980's," Journal of Labor Economics 17(4) part 1, 1999, pp. 757:783.

Blundell, Richard and Paul Johnson, "Pensions and Retirement in the U.K.," Working Paper No. 6154, Cambridge, Massachusetts: National Bureau of Economic Research, September 1997.

Centers for Medicare and Medicaid Services, "Medicare and Other Health Benefits: Your Guide to Who Pays First," Baltimore, MD: Centers for Medicare and Medicaid Services, 2005, http://www.medicare.gov/Publications/Pubs/pdf/02179.pdf

Costa, Dora L., The Evolution of Retirement: An American Economic History, 19901990, Chicago: The University of Chicago Press, 1998.

Currie, Janet and Brigitte C. Madrian, "Health, Health Insurance and the Labor Market" in Orley Ashenfelter and David Card, eds., Handbook of Labor Economics, Volume 3C, Amsterdam: North Holland, 1999, pp. 3309-3416.

Fuchs, Victor R., "Self-Employment and Labor Force Participation of Older Males," Journal of Human Resources, Vol. 17, No. 3, Summer 1982, pp. 339-357.

Gruber, Jonathan, and David Wise, eds., Social Security and Retirement Around the World, Chicago: University of Chicago Press, 1999.

Gruber, Jonathan and Brigitte Madrian, "Health Insurance, Labor Supply and Job Mobility: A Critical Review of the Literature," NBER Working Paper 8817, 2002.

Hochguertel, Stefan, "Self-Employment around Retirement in Europe," Working Paper, Free University Amsterdam, 2005.

Holtz-Eakin, Douglas, David Joulfaian, and Harvey S. Rosen, "The Carnegie Conjecture: Some Empirical Evidence," Quarterly Journal of Economics, Vol. 108, No. 2, 1993, pp. 413-435.

Hurd, Michael D., "Research on the Elderly: Economic Status, Retirement, and Consumption and Savings," Journal of Economic Literature, Vol. 28, June 1990a, pp. 565-637.

Hurd, Michael D., "Labor Market Transitions in the HRS: Effects of the Subjective Probability of Retirement and of Pension Eligibility," in James P. Smith and 
Robert J. Willis, eds., Wealth, Work, and Health, Ann Arbor, MI: University of Michigan Press, 1999b, pp. 267-290.

Hurd, Michael D. and Michael J. Boskin, "The Effect of Social Security on Retirement in the Early 1970s," Quarterly Journal of Economics, Vol. 99, No. 4, November 1984, pp. 767-790.

Hurd, Michael D. and Kathleen McGarry, "The Relationship Between Job Characteristics and Retirement," Working Paper No. 4558, Cambridge, Massachusetts: National Bureau of Economic Research, 1993.

Hurd, Michael D., and Monika Reti, "The Effects of Large Capital Gains on Work and Consumption: Evidence from Four Waves of the HRS," working paper, Santa Monica, California: The RAND Corporation, October 2001.

Hurd, Michael D., James Smith, and Julie Zissimopoulos, "The Effects of Subjective Survival on Retirement and Social Security Claiming," Journal of Applied Econometrics, Vol. 18, No. 0, 2003.

Ippolito, Richard A., "Toward Explaining Early Retirement After 1970," Industrial and Labor Relations Review, Vol. 43, No. 5, 1990, pp. 556-569.

Juster, F. Thomas and James P. Smith, "Improving the Quality of Economic Data: Lessons from HRS and AHEAD," Journal of the American Statistical Association, Vol. 92, No. 440, December 1997, pp. 1268-1278.

Karoly, Lynn A. and Constantijn W.A. Panis, The $21^{\text {st }}$ Century at Work: Forces Shaping the Future Workforce and Workplace in the United States, MG-164, Santa Monica, CA: The RAND Corporation, 2004.

Lumsdaine, Robin L. and Olivia S. Mitchell, "New Developments in the Economic Analysis of Retirement," in Orley Ashenfelter and David Card, eds., Handbook of Labor Economics, Volume 3C, Amsterdam: North Holland, 1999, pp. 32613307.

Lusardi, Annamaria, "Planning and Saving for Retirement," Dartmouth College Working Paper, 2003.

Meghir, C and E. Whitehouse, "Labour Market Transitions and Retirement of Men in the U.K.," Journal of Econometrics, Vol. 79, 1997, pp. 327-354.

Parker, Simon and Jonathan Rougier, "The Retirement Behavior of the Self-Employed in Britain," Applied Economics, Vol. 39, 2007, pp. 697-713.

Quinn, Joseph F., "Retirement Patterns and Bridge Jobs in the 1990s," Employee Benefits Research Institute Issue Brief No. 206, Washington, D.C: EBRI, 1999. 
Sammartino, Frank, "The Effect of Health on Retirement," Social Security Bulletin, Vol. 50, February 1987, pp. 31-47.

Samwick, Andrew A., "New Evidence on Pensions, Social Security and the Timing of Retirement," Journal of Public Economics, Vol. 70, November 1998, pp. 207236.

Sevak, Purvi, "Wealth Shocks and Retirement Timing: Evidence from the Nineties," Working Paper No. 2002-027, Ann Arbor, Michigan: Michigan Retirement Research Center, 2002.

Zissimopoulos, Julie and Michael Hurd, "Saving for Retirement: Wage Growth and Unexpected Events," paper presented at the 2002 NBER Summer Institute on Aging, under review at Review of Income and Wealth, December 2003.

Zissimopoulos, Julie and Lynn A. Karoly, "Transitions to Self-Employment at Older Ages: The Role of Wealth, Health, Health Insurance, and Other Factors," Labour Economics, Vol. 14, 2007a, pp. 269-295.

Zissimopoulos, Julie and Lynn A. Karoly, "Work and Well Being Among the SelfEmployed at Older Ages," Washington, D.C.: AARP, $2007 \mathrm{~b}$. 
Table 1-Rates of Self-Employment among Older Workers by Age in 12 Countries (percentage)

\begin{tabular}{lcccc}
\hline & \multicolumn{4}{c}{ Age group } \\
\cline { 2 - 5 } Country & 50 to 55 & 56 to 59 & 60 to 64 & 65 and above \\
\hline Austria & 16.1 & 19.9 & 35.1 & 50.4 \\
Denmark & 8.0 & 11.8 & 17.9 & 25.9 \\
England & 16.4 & 16.6 & 20.0 & 39.9 \\
France & 12.4 & 10.8 & 22.2 & 47.3 \\
Germany & 14.3 & 14.7 & 19.9 & 38.1 \\
Greece & 36.1 & 40.2 & 50.1 & 61.6 \\
Italy & 29.6 & 36.4 & 58.0 & 71.5 \\
Netherlands & 12.5 & 11.7 & 30.2 & 43.7 \\
Spain & 26.3 & 33.1 & 28.5 & 68.0 \\
Sweden & 13.3 & 11.5 & 14.5 & 36.2 \\
Switzerland & 17.8 & 24.4 & 33.0 & 59.1 \\
United States & 18.6 & 18.5 & 22.8 & 36.5 \\
\hline
\end{tabular}

NOTE: Response rates differ across the SHARE countries. The rate is especially low in Switzerland (38 percent) so the figures for that country should be interpreted with caution. Percentages have been calculated using HRS, ELSA, and SHARE sampling weights.

SOURCE: Authors' calculations using HRS 2002 and wave 1 of ELSA and SHARE. 


\section{Table 2-Rates of Self-Employment and Distribution by Self-Employment Category in the HRS and ELSA \\ (percent distribution)}

\begin{tabular}{|c|c|c|c|c|c|c|}
\hline \multirow[b]{3}{*}{ County and subgroup } & \multirow{2}{*}{\multicolumn{2}{|c|}{ All workers }} & \multicolumn{4}{|c|}{ Self-employed } \\
\hline & & & \multicolumn{2}{|c|}{$\begin{array}{c}\text { By age of } \\
\text { self-employment }\end{array}$} & \multicolumn{2}{|c|}{$\begin{array}{c}\text { By presence of } \\
\text { employees }\end{array}$} \\
\hline & $\begin{array}{l}\text { Wage and } \\
\text { salary }\end{array}$ & $\begin{array}{c}\text { Self- } \\
\text { employed }\end{array}$ & $\begin{array}{l}\text { Before } \\
\text { age } 50\end{array}$ & $\begin{array}{l}\text { At or after } \\
\text { age } 50\end{array}$ & $\begin{array}{l}\text { Without } \\
\text { employees }\end{array}$ & $\begin{array}{c}\text { With } \\
\text { employees }\end{array}$ \\
\hline United States & 78.1 & 21.9 & 67.8 & 32.2 & 38.9 & 61.1 \\
\hline Males & 73.4 & 26.6 & 69.8 & 30.2 & 18.1 & 81.9 \\
\hline Females & 83.2 & 16.8 & 64.1 & 35.9 & 48.6 & 51.4 \\
\hline England & 80.3 & 19.7 & 56.9 & 43.1 & 80.2 & 19.8 \\
\hline Males & 75.4 & 24.6 & 60.0 & 40.0 & 78.9 & 21.1 \\
\hline Females & 86.7 & 13.3 & 49.7 & 50.3 & 83.1 & 16.9 \\
\hline
\end{tabular}

NOTE: Sample is individuals age 55 to 70 . Sample size for HRS is 4,491 and for ELSA is 2,349. Percentages have been calculated using HRS and ELSA sampling weights. Missing observations for U.S as follows: 3 workers unclassified by class; 13 self-employed workers not classified by age; 27 self-employed workers not classified by presence of employees. Missing observations for England as follows: 27 workers unclassified by class; 8 selfemployed workers not classified by age; 50 self-employed workers not classified by presence of employees. The percentage of self-employed workers in England with employees among the non-missing observations is approximately $14 \%$ lower than as reported in the U.K. census for England and Wales. Respondents in the unclassified group are likely to have employees because their income and wealth are on average similar to those self-employed with employees.

SOURCE: Authors' calculations using the 2002 waves of HRS and ELSA. 
Table 3-Worker Characteristics by Employment Class in the HRS and ELSA (percent distribution)

\begin{tabular}{|c|c|c|c|c|}
\hline & \multicolumn{2}{|c|}{ United States } & \multicolumn{2}{|c|}{ England } \\
\hline & $\begin{array}{l}\text { Wage and } \\
\text { salary }\end{array}$ & $\begin{array}{c}\text { Self- } \\
\text { employed }\end{array}$ & $\begin{array}{c}\text { Wage and } \\
\text { salary }\end{array}$ & $\begin{array}{c}\text { Self- } \\
\text { employed }\end{array}$ \\
\hline Male & 49.5 & 63.8 & 52.7 & 70.3 \\
\hline \multicolumn{5}{|l|}{ Age group } \\
\hline 55 to 59 & 54.6 & 43.4 & 62.6 & 51.0 \\
\hline 60 to 61 & 16.3 & 14.5 & 14.0 & 12.5 \\
\hline 62 to 64 & 13.9 & 17.2 & 14.5 & 16.6 \\
\hline 65 to 70 & 15.3 & 25.0 & 8.9 & 20.0 \\
\hline Married & 70.5 & 74.7 & 77.0 & 74.1 \\
\hline Foreign born & 8.3 & 8.9 & 6.5 & 6.2 \\
\hline \multicolumn{5}{|l|}{ Health status } \\
\hline Excellent & 17.1 & 25.3 & 9.0 & 10.9 \\
\hline Very good & 38.0 & 34.7 & 34.3 & 36.7 \\
\hline Good & 31.8 & 29.0 & 39.5 & 37.4 \\
\hline Fair & 11.3 & 9.6 & 15.2 & 13.3 \\
\hline Poor & 1.8 & 1.4 & 2.0 & 1.7 \\
\hline Works part time & 17.1 & 32.1 & 35.1 & 35.2 \\
\hline \multicolumn{5}{|l|}{ Income } \\
\hline Quartile 1 (low) & 6.7 & 10.6 & 7.0 & 12.7 \\
\hline Quartile 2 & 15.8 & 11.8 & 15.1 & 17.5 \\
\hline Quartile 3 & 30.5 & 21.0 & 33.0 & 27.3 \\
\hline Quartile 4 (high) & 47.0 & 56.7 & 44.9 & 42.6 \\
\hline \multicolumn{5}{|l|}{ Wealth } \\
\hline Quartile 1 (low) & 20.0 & 11.5 & 15.8 & 8.7 \\
\hline Quartile 2 & 28.4 & 13.4 & 26.6 & 16.8 \\
\hline Quartile 3 & 27.9 & 25.8 & 29.1 & 25.8 \\
\hline Quartile 4 (high) & 23.7 & 49.3 & 28.5 & 48.7 \\
\hline Sample size (N) & 3,480 & 1,006 & 1,906 & 466 \\
\hline
\end{tabular}


Table 4-Health Insurance Coverage of Workers Under Age 65 by Employment Class in the HRS

(percent distribution)

\begin{tabular}{lcc}
\hline & \multicolumn{2}{c}{ United States } \\
\hline Employer provided, no retiree benefits & 59.7 & Self-employed \\
Employer provided, retiree benefits & 16.3 & 37.8 \\
Spousal benefits & 16.0 & 1.8 \\
Other source (incl. government) & 9.6 & 24.6 \\
None & 6.2 & 25.7 \\
Sample size (N) & 2,551 & 15.3 \\
\hline
\end{tabular}

NOTE: Sample is individuals age 55 to 70 . Percentages have been calculated using HRS sampling weights. Insurance types are not mutually exclusive and thus do not add to 100 percent.

SOURCE: Authors' calculations using the 2002 wave of HRS.

\section{Table 5-Pension Coverage by Employment Class and Self-Employment Category in the HRS and ELSA (percent distribution)}

\begin{tabular}{|c|c|c|c|c|c|c|}
\hline \multirow[b]{3}{*}{ Pension measure } & \multicolumn{3}{|c|}{ United States } & \multicolumn{3}{|c|}{ England } \\
\hline & \multicolumn{2}{|c|}{ By employment class } & \multirow[b]{2}{*}{$\begin{array}{c}\text { All } \\
\text { workers }\end{array}$} & \multicolumn{2}{|c|}{ By employment class } & \multirow[b]{2}{*}{$\begin{array}{c}\text { All } \\
\text { workers }\end{array}$} \\
\hline & $\begin{array}{c}\text { Wage and } \\
\text { salary }\end{array}$ & $\begin{array}{c}\text { Self- } \\
\text { employed }\end{array}$ & & $\begin{array}{l}\text { Wage and } \\
\text { salary }\end{array}$ & $\begin{array}{c}\text { Self- } \\
\text { employed }\end{array}$ & \\
\hline Has pension on current job & 63.5 & 11.9 & 52.1 & 60.8 & 39.2 & 56.4 \\
\hline \multicolumn{7}{|c|}{ Pension type given that have a pension } \\
\hline Defined contribution & 42.6 & 63.7 & 43.7 & 44.9 & 95.8 & 51.8 \\
\hline Defined benefit & 35.3 & 13.6 & 34.2 & 44.2 & 2.5 & 38.4 \\
\hline Both & 19.0 & 9.1 & 18.5 & 4.0 & 1.0 & 3.5 \\
\hline Don’t know & 3.1 & 13.6 & 3.7 & 7.0 & 1.0 & 6.3 \\
\hline Sample size $(N)$ & 3,446 & 996 & 4,442 & 1,897 & 464 & 2,361 \\
\hline
\end{tabular}

NOTE: Sample is individuals age 55 to 70 . Percentages have been calculated using HRS and ELSA sampling weights. In the HRS (ELSA), 34 (9) wage and salary workers and 10 (2) self-employed workers have missing values for pension ownership.

SOURCE: Authors' calculations using the 2002 waves of HRS and ELSA. 


\section{Table 6-Regression Results for Labor Force Exits in the HRS and ELSA, Fully Interacted Model by Employment Class and Country}

\begin{tabular}{|c|c|c|c|c|c|c|c|c|}
\hline & \multicolumn{4}{|c|}{ United States } & \multicolumn{4}{|c|}{ England } \\
\hline & \multicolumn{2}{|c|}{ Self-employed } & \multicolumn{2}{|c|}{ Wage } & \multicolumn{2}{|c|}{ Self-employed } & \multicolumn{2}{|c|}{ Wage } \\
\hline & Coeff. & S.E. & Coeff. & S.E. & Coeff. & S.E. & Coeff. & S.E. \\
\hline Class of worker \& country intercept & 17.247 & 11.261 & 5.014 & 4.816 & 2.938 & 16.312 & 10.046 & 7.109 \\
\hline \multicolumn{9}{|l|}{ Demographics, self-reported health: } \\
\hline Male & -0.028 & 0.025 & -0.002 & 0.013 & -0.049 & 0.038 & -0.033 & 0.018 \\
\hline Married & 0.011 & 0.029 & 0.003 & 0.016 & 0.049 & 0.037 & 0.014 & 0.018 \\
\hline \multicolumn{9}{|l|}{ Health status [good] } \\
\hline Health excellent/very good & -0.025 & 0.025 & -0.029 & 0.014 & -0.050 & 0.033 & -0.050 & 0.016 \\
\hline Health fair/poor & 0.064 & 0.036 & 0.046 & 0.020 & 0.096 & 0.048 & 0.092 & 0.021 \\
\hline \multicolumn{9}{|l|}{ Wealth \& Income quartiles [Q2Q3] } \\
\hline Wealth Q1, Income Q1 & 0.207 & 0.061 & 0.043 & 0.033 & 0.042 & 0.092 & 0.083 & 0.041 \\
\hline Wealth Q1, Income Q2Q3 & 0.091 & 0.053 & -0.027 & 0.020 & 0.007 & 0.074 & -0.036 & 0.027 \\
\hline Wealth Q1, Income Q4 & 0.121 & 0.082 & -0.100 & 0.040 & & & -0.046 & 0.044 \\
\hline Wealth Q2Q3, Income Q1 & 0.081 & 0.054 & -0.020 & 0.037 & 0.067 & 0.068 & 0.104 & 0.041 \\
\hline Wealth Q2Q3, Income Q4 & -0.068 & 0.037 & -0.027 & 0.018 & -0.028 & 0.050 & -0.011 & 0.021 \\
\hline Wealth Q4, Income Q1 & -0.115 & 0.092 & 0.232 & 0.132 & 0.053 & 0.079 & 0.036 & 0.066 \\
\hline Wealth Q4, Income Q2Q3 & -0.029 & 0.042 & 0.035 & 0.030 & -0.097 & 0.050 & 0.026 & 0.032 \\
\hline Wealth Q4, Income Q4 & -0.066 & 0.031 & -0.040 & 0.020 & -0.008 & 0.043 & -0.006 & 0.022 \\
\hline \multicolumn{9}{|l|}{ Private pensions (none): } \\
\hline Has DC pension & -0.070 & 0.050 & -0.052 & 0.017 & -0.116 & 0.035 & -0.127 & 0.020 \\
\hline \multicolumn{9}{|l|}{ Has DB pension w/benefit age $\mathrm{e}^{1}$} \\
\hline P1. ERA \& NRA $<$ PEA & & & 0.080 & 0.033 & & & -0.007 & 0.132 \\
\hline P2. ERA $<$ PEA, NRA $\geq$ PEA $\&<$ PNA & & & -0.111 & 0.062 & & & -0.043 & 0.034 \\
\hline P3. ERA $<$ PEA, NRA $\geq$ PNA & & & 0.015 & 0.056 & & & -0.056 & 0.054 \\
\hline P4. ERA and NRA $\geq$ PEA $\&<$ PNA, & & & -0.008 & 0.078 & & & -0.143 & 0.062 \\
\hline P5. ERA $\geq$ PEA $\&<$ PNA, NRA $\geq$ PNA & & & 0.103 & 0.094 & & & -0.075 & 0.075 \\
\hline P6. ERA and NRA $\geq$ PNA & & & 0.046 & 0.091 & & & & \\
\hline P7. Missing ERA, NRA $<$ PEA & & & 0.019 & 0.075 & & & -0.096 & 0.094 \\
\hline P8. Missing ERA, NRA $\geq$ PEA $\&<$ PNA & & & -0.049 & 0.125 & & & -0.122 & 0.031 \\
\hline P9. Missing ERA, NRA $\geq$ PNA & & & -0.090 & 0.103 & & & -0.141 & 0.052 \\
\hline P10. Missing ERA \& NRA & & & -0.054 & 0.034 & & & -0.071 & 0.040 \\
\hline \multirow{2}{*}{\multicolumn{9}{|c|}{$\begin{array}{l}\text { DB type*indicator if PEA } \leq \text { age } ’ 04 \leq \text { PNA } \\
\text { (Age04_PEA) }\end{array}$}} \\
\hline & & & & & & & & \\
\hline P1* A Age04_PEA & & & 0.040 & 0.072 & & & & \\
\hline P2* Age04_PEA & & & 0.190 & 0.106 & & & -0.067 & 0.079 \\
\hline P3*Age04_PEA & & & 0.010 & 0.111 & & & 0.006 & 0.105 \\
\hline P4*Age04_PEA & & & 0.287 & 0.080 & & & 0.215 & 0.108 \\
\hline P5*Age04_PEA & & & 0.013 & 0.106 & & & -0.043 & 0.126 \\
\hline P6*Age04_PEA & & & -0.037 & 0.098 & & & & \\
\hline P7*Age04_PEA & & & 0.052 & 0.167 & & & & \\
\hline P8*Age04_PEA & & & 0.014 & 0.204 & & & 0.234 & 0.060 \\
\hline P9* Age04_PEA & & & 0.053 & 0.204 & & & 0.002 & 0.094 \\
\hline P10*Age0 $\overline{4} \_$PEA & & & 0.058 & 0.058 & & & 0.075 & 0.080 \\
\hline \multirow{2}{*}{\multicolumn{9}{|c|}{$\begin{array}{l}\text { DB type*indicator if PNA } \leq \text { age '04 } \\
\text { (Age04_PNA) }\end{array}$}} \\
\hline & & & & & & & & \\
\hline P1*Ā Age 04 PNA & & & -0.140 & 0.074 & & & & \\
\hline P2*Age04_PNA & & & 0.378 & 0.145 & & & & \\
\hline P3*Age04_PNA & & & 0.014 & 0.137 & & & 0.012 & 0.187 \\
\hline P4*Age04_PNA & & & 0.328 & 0.086 & & & & \\
\hline P5*Age04_PNA & & & 0.229 & 0.135 & & & -0.055 & 0.213 \\
\hline P6*Age04_PNA & & & 0.131 & 0.092 & & & & \\
\hline P7*Age04_PNA & & & 0.120 & 0.166 & & & & \\
\hline P8*Age04_PNA & & & 0.290 & 0.305 & & & & \\
\hline P9*Age04_PNA & & & 0.083 & 0.157 & & & 0.189 & 0.124 \\
\hline P10*Age 04 PNA & & & 0.018 & 0.051 & & & 0.272 & 0.147 \\
\hline
\end{tabular}




\section{Table 6-Regression Results for Transition to Retirement in the HRS and ELSA, Fully Interacted Model by Employment Class and Country, Continued}

\begin{tabular}{|c|c|c|c|c|c|c|c|c|}
\hline & \multicolumn{4}{|c|}{ United States } & \multicolumn{4}{|c|}{ England } \\
\hline & \multicolumn{2}{|c|}{ Self-employed } & \multicolumn{2}{|c|}{ Wage } & \multicolumn{2}{|c|}{ Self-employed } & \multicolumn{2}{|c|}{ Wage } \\
\hline & Coeff. & S.E. & Coeff. & S.E. & Coeff. & S.E. & Coeff. & S.E. \\
\hline \multicolumn{9}{|l|}{ Age and age interactions: } \\
\hline Age 04 & -0.609 & 0.393 & -0.178 & 0.169 & -0.098 & 0.587 & -0.369 & 0.256 \\
\hline Age04 squared & 0.005 & 0.003 & 0.002 & 0.001 & 0.001 & 0.005 & 0.003 & 0.002 \\
\hline Indicator if PEA $\leq$ age' $04 \leq$ PNA & & & & & & & & \\
\hline (Age04_PEA) & -80.280 & 212.786 & 28.615 & 111.079 & -7.660 & 16.744 & -13.593 & 7.227 \\
\hline Age04_PEA*Age04 & 2.634 & 6.757 & -0.860 & 3.528 & 0.231 & 0.597 & 0.466 & 0.259 \\
\hline Age04 PEA*Age04-squared & -0.022 & 0.054 & 0.006 & 0.028 & -0.002 & 0.005 & -0.004 & 0.002 \\
\hline Indicator if PNA $\leq$ age'04 (Age04 PNA) & -17.885 & 11.430 & -2.985 & 5.235 & 3.979 & 17.331 & -2.567 & 8.586 \\
\hline Age04_PNA*Age04 & 0.623 & 0.397 & 0.129 & 0.178 & -0.085 & 0.608 & 0.165 & 0.289 \\
\hline Age04_PNA*Age04-squared & -0.005 & 0.003 & -0.001 & 0.002 & 0.000 & 0.005 & -0.002 & 0.002 \\
\hline \multicolumn{9}{|l|}{ Health insurance and RHB: } \\
\hline Employer HI no RHB and Age $04<65$ & -0.002 & 0.048 & 0.001 & 0.025 & & & & \\
\hline Spousal HI and Age $04<65$ & 0.078 & 0.050 & 0.035 & 0.027 & & & & \\
\hline Other $\mathrm{HI}$ and Age $04<65$ & 0.087 & 0.048 & 0.059 & 0.029 & & & & \\
\hline Employer HI with RHB and Age $04<65$ & & & 0.011 & 0.030 & & & & \\
\hline Employer HI w/out RHB and Age04 65+ & -0.012 & 0.035 & -0.023 & 0.023 & & & & \\
\hline Spousal HI and Age04 65+ & 0.059 & 0.049 & -0.007 & 0.036 & & & & \\
\hline Other HI and Age04 65+ & 0.070 & 0.046 & -0.006 & 0.031 & & & & \\
\hline Employer HI with RHB and Age04 65+ & & & 0.088 & 0.049 & & & & \\
\hline
\end{tabular}

NOTES: Columns do not represent separate equations, but rather coefficients refer to the covariate in each row interacted with a variable for the country and class indicated in the column heading. Results based on fully interacted model. Sample size is 8,989. Model R-squared is 0.315 . Indicates coefficient is statistically significant at the $* * * 1$ percent, $* * 5$ percent, and $* 10$ percent level.

(1) Few self-employed workers in the U.S. report having DB plans thus the categories of type by age of early and normal benefits are collapsed to two categories with coefficients (standard errors) as follows: ERA \& NRA < PEA -0.119 (0.060); ERA or NRA at PEA or PNA -0.011 (0.120).

(2) $\mathrm{PEA}=$ Public early eligibility age, PNA=Public normal (standard) eligibility age, ERA=Early retirement age of private pension, $\mathrm{NRA}=$ Normal retirement age of private pension, $\mathrm{RHB}=$ Retiree health benefits.

SOURCE: Authors' calculations using the 2002 and 2004 waves of HRS and ELSA. 


\section{Table 7-Predicted Percentage of Workers Exiting Labor Force Between Waves by}

Employment Class and Age Began Self-Employment Work in the HRS and ELSA

\begin{tabular}{|c|c|c|c|c|c|c|}
\hline \multirow[b]{3}{*}{ Age } & \multicolumn{3}{|c|}{ United States } & \multicolumn{3}{|c|}{ England } \\
\hline & \multicolumn{2}{|c|}{ Self-employed } & \multirow{2}{*}{$\begin{array}{c}\text { Wage \& Salary } \\
\text { All }\end{array}$} & \multicolumn{2}{|c|}{ Self-employed } & \multirow{2}{*}{$\begin{array}{c}\text { Wage \& Salary } \\
\text { All }\end{array}$} \\
\hline & Before Age 50 & All & & Before Age 50 & All & \\
\hline 55 & 6.41 & 8.62 & 13.05 & 9.86 & 19.71 & 16.29 \\
\hline 56 & 5.44 & 7.64 & 13.35 & 9.97 & 19.61 & 17.64 \\
\hline 57 & 5.29 & 7.74 & 13.97 & 11.17 & 19.68 & 19.67 \\
\hline 58 & 5.95 & 8.92 & 14.93 & 13.48 & 19.93 & 22.40 \\
\hline 59 & 7.43 & 11.17 & 16.20 & 16.88 & 20.35 & 25.81 \\
\hline 60 & 9.73 & 14.51 & 17.81 & 21.49 & 23.45 & 30.48 \\
\hline 61 & 12.84 & 18.93 & 19.74 & 23.70 & 26.53 & 33.62 \\
\hline 62 & 18.46 & 20.07 & 24.08 & 25.78 & 29.45 & 36.64 \\
\hline 63 & 14.72 & 19.87 & 21.04 & 27.74 & 32.19 & 39.56 \\
\hline 64 & 16.49 & 16.42 & 19.63 & 29.59 & 34.76 & 42.37 \\
\hline 65 & 11.67 & 16.78 & 36.43 & 37.19 & 48.84 & 60.37 \\
\hline 66 & 11.22 & 17.81 & 36.13 & 36.61 & 47.48 & 59.79 \\
\hline 67 & 11.00 & 18.83 & 35.90 & 36.32 & 46.38 & 59.51 \\
\hline 68 & 11.00 & 19.84 & 35.74 & 36.31 & 45.53 & 59.54 \\
\hline 69 & 11.22 & 20.85 & 35.65 & 36.57 & 44.95 & 59.86 \\
\hline 70 & 11.66 & 21.85 & 35.64 & 37.12 & 44.62 & 60.49 \\
\hline
\end{tabular}

NOTES: Results for column 'All' based on predictions from fully interacted model given in Table 6. Sample size is 8,989. Model R-squared is 0.315 . Results for columns 'Before Age 50' based on predictions from fully interacted model with self-employed workers who became selfemployed before age 50 and all wage workers. Sample size is 8,203. Model adjusted R-squared is 0.313 .

SOURCE: Authors' calculations using the 2002 and 2004 waves of HRS and ELSA.

Table 8-Predicted Percentage of Self-Employed Exiting Labor Force Between Waves by Age Began Self-Employment in the HRS and ELSA: Assuming U.S. Self-Employed Have Access to Health Insurance Benefits Through Spouse or Non-employment Source

\begin{tabular}{cccc}
\hline & \multicolumn{2}{c}{ U.S.: Self-employed } & \multicolumn{2}{c}{ England: Self-employed } \\
\hline Age & Before age 50 & All & Before age 50 \\
55 & 22.16 & 16.64 & 9.86 \\
56 & 21.19 & 15.66 & 9.97 \\
57 & 21.04 & 15.76 & 11.17 \\
58 & 21.70 & 16.94 & 13.48 \\
59 & 23.18 & 19.20 & 16.88 \\
60 & 25.48 & 22.53 & 21.49 \\
61 & 28.59 & 26.95 & 23.70 \\
62 & 34.21 & 28.09 & 25.78 \\
63 & 30.47 & 27.89 & 27.74 \\
64 & 32.24 & 24.44 & 29.59 \\
66 & 36.74 & 30.78 & 37.19 \\
67 & 36.29 & 31.81 & 36.61 \\
69 & 36.07 & 32.83 & 36.32 \\
70 & 36.07 & 33.84 & 36.31
\end{tabular}

NOTES: Results for column 'All' based on predictions from fully interacted model given in Table 6. Sample size is 8,989. Model R-squared is 0.315 . Results for columns 'Before Age 50' based on predictions from fully interacted model with self-employed workers who became selfemployed before age 50 and all wage workers. Sample size is 8,203. Model adjusted R-squared is 0.313.

SOURCE: Authors' calculations using the 2002 and 2004 waves of HRS and ELSA. 
Figure 1-Pension Plan NRA for Wage Workers in the HRS and ELSA

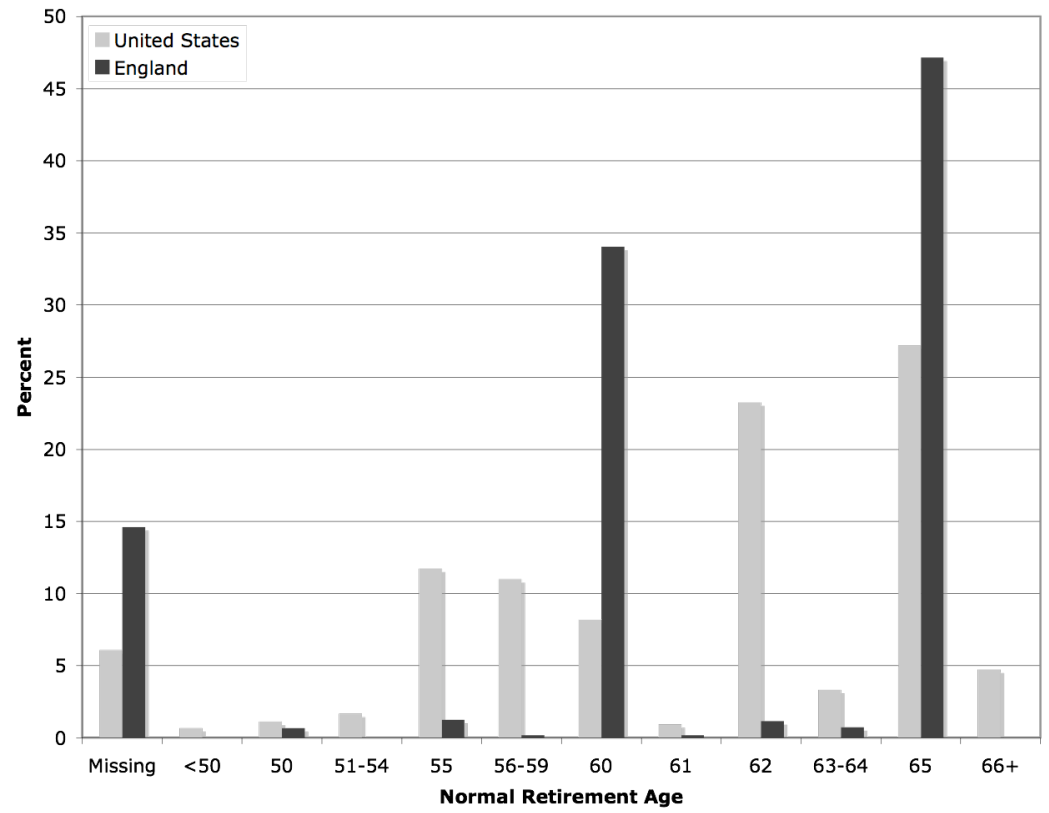

NOTE: Sample is individuals age 55 to 70 . Percentages have been calculated using HRS and ELSA sampling weights. SOURCE: Authors' calculations using the 2002 waves of HRS and ELSA.

Figure 2-Pension Plan ERA for Wage Workers in the HRS and ELSA

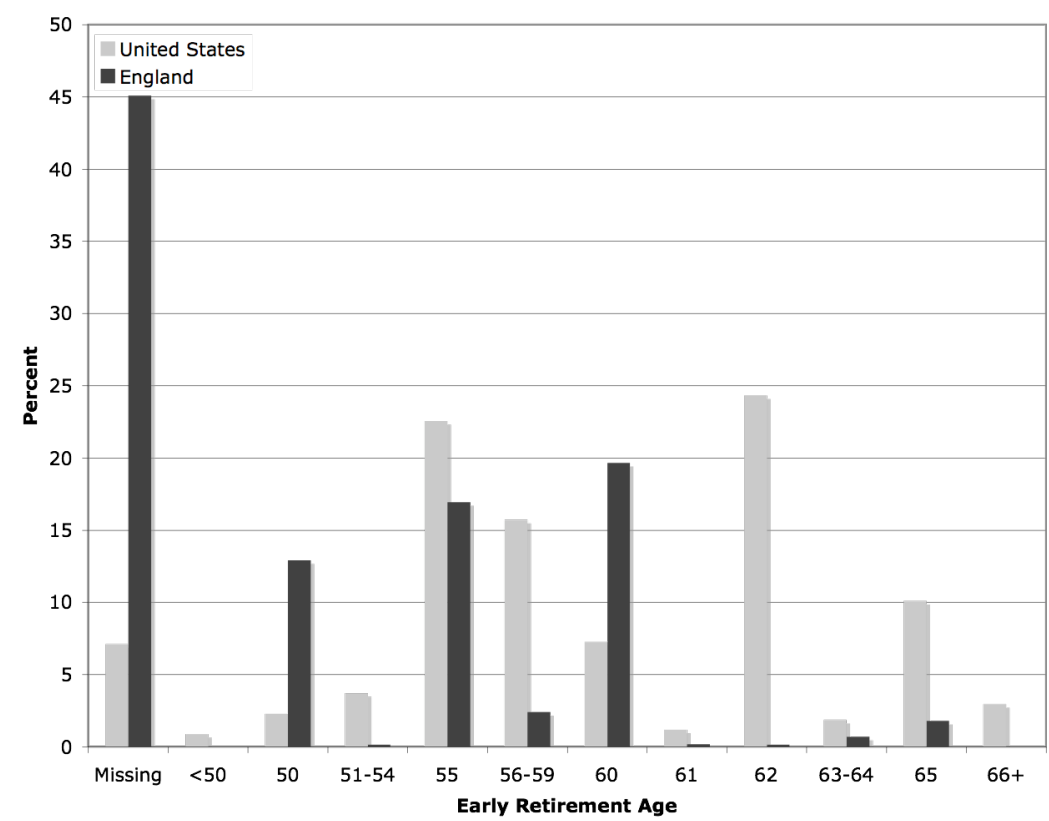

NOTE: Sample is individuals age 55 to 70 . Percentages have been calculated using HRS and ELSA sampling weights. SOURCE: Authors' calculations using the 2002 waves of HRS and ELSA. 
Figure 3-Observed Percentage Exiting Labor Force Between Waves by Employment Class in the HRS and ELSA

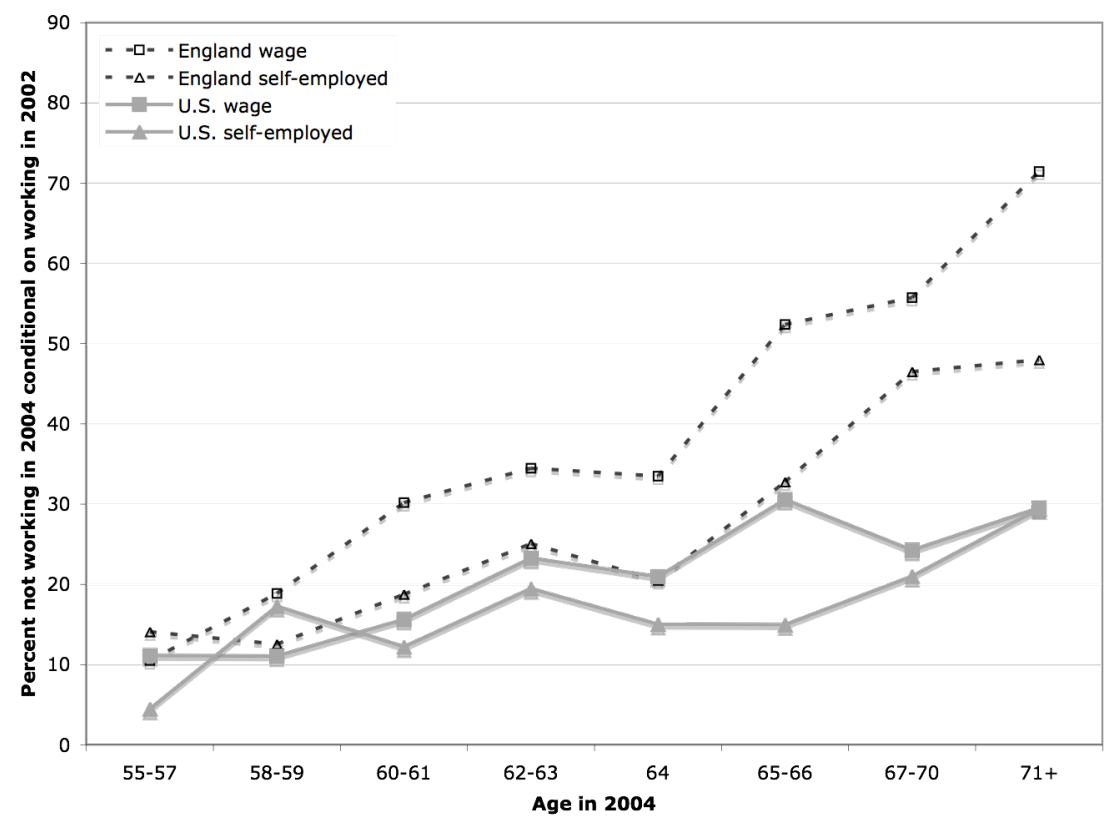

NOTE: Results are plotted for individuals age 55 to 70 in 2002. Percentages have been calculated using HRS and ELSA sampling weights.

SOURCE: Authors' calculations using the 2002 and 2004 waves of HRS and ELSA.

\section{Figure 4-Predicted Percentage Exiting Labor Force Between Waves by Employment Class in the HRS and ELSA}

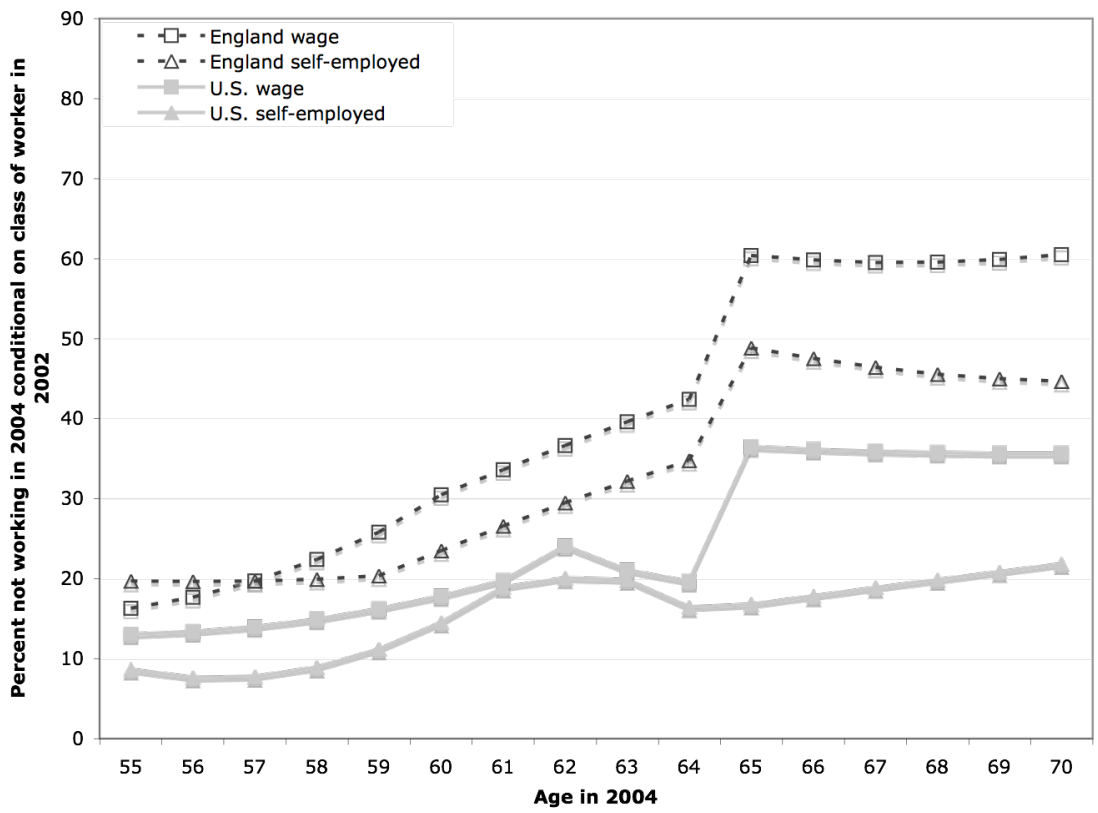

NOTE: Predicted probabilities based on regression results reported in Table 6.

SOURCE: Authors' calculations using the 2002 and 2004 waves of HRS and ELSA. 
Figure 5-Predicted Percentage Exiting Labor Force Between Waves by Employment Class in the HRS and ELSA: Assuming U.S. Workers Have Access to Nonemployer Provided Health Insurance Benefits or Retiree Benefits

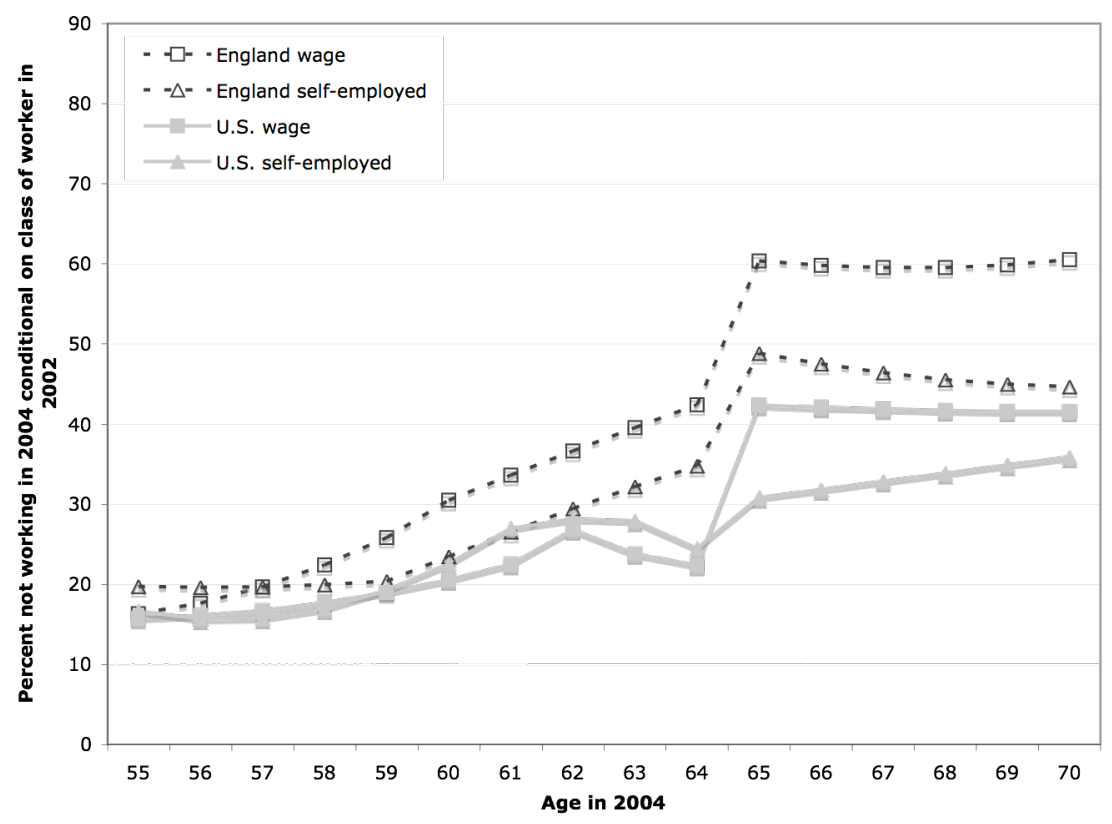

NOTE: Predicted probabilities based on regression results reported in Table 6 .

SOURCE: Authors' calculations using the 2002 and 2004 waves of HRS and ELSA.

Figure 6-Predicted Percentage Exiting Labor Force Between Waves by Employment Class in the HRS and ELSA: Wage Workers Have DC Pensions

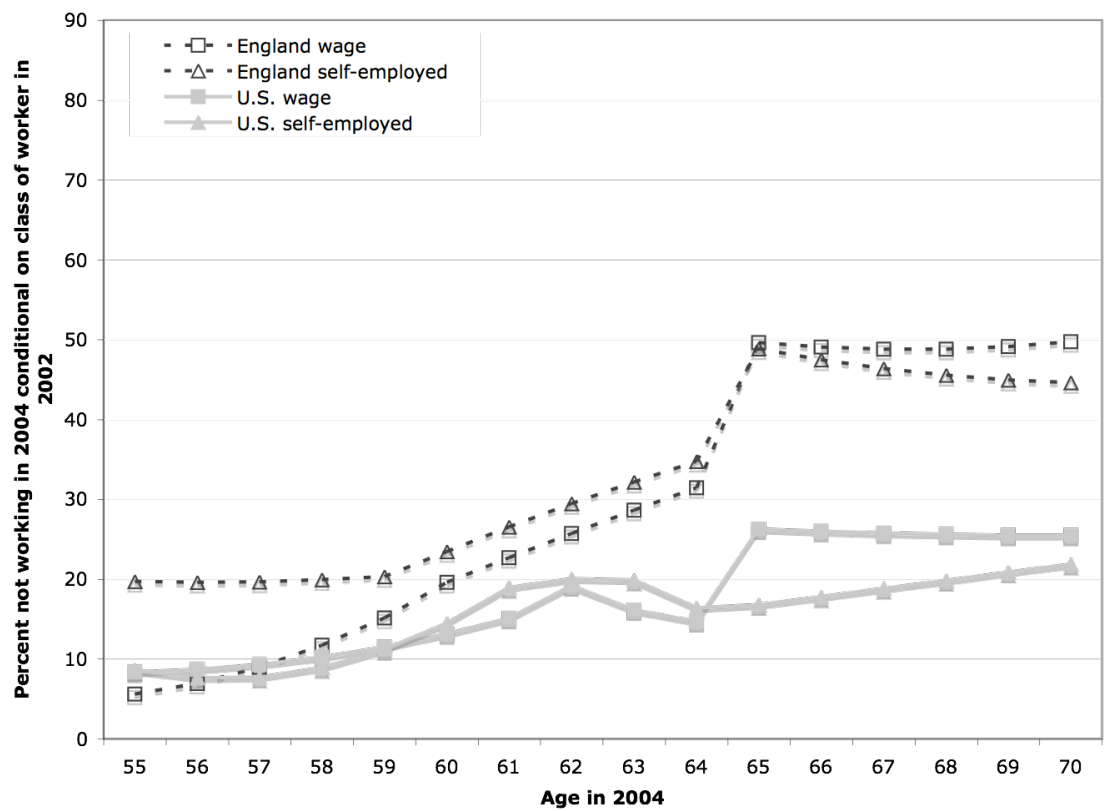

NOTE: Predicted probabilities based on regression results reported in Table 6 .

SOURCE: Authors' calculations using the 2002 and 2004 waves of HRS and ELSA. 
Figure 7-Predicted Percentage Exiting Labor Force Between Waves by Employment Class in the HRS and ELSA: Assuming All Wage and Salary Workers Have DB Pensions with ERA and NRA at Public Benefit Ages

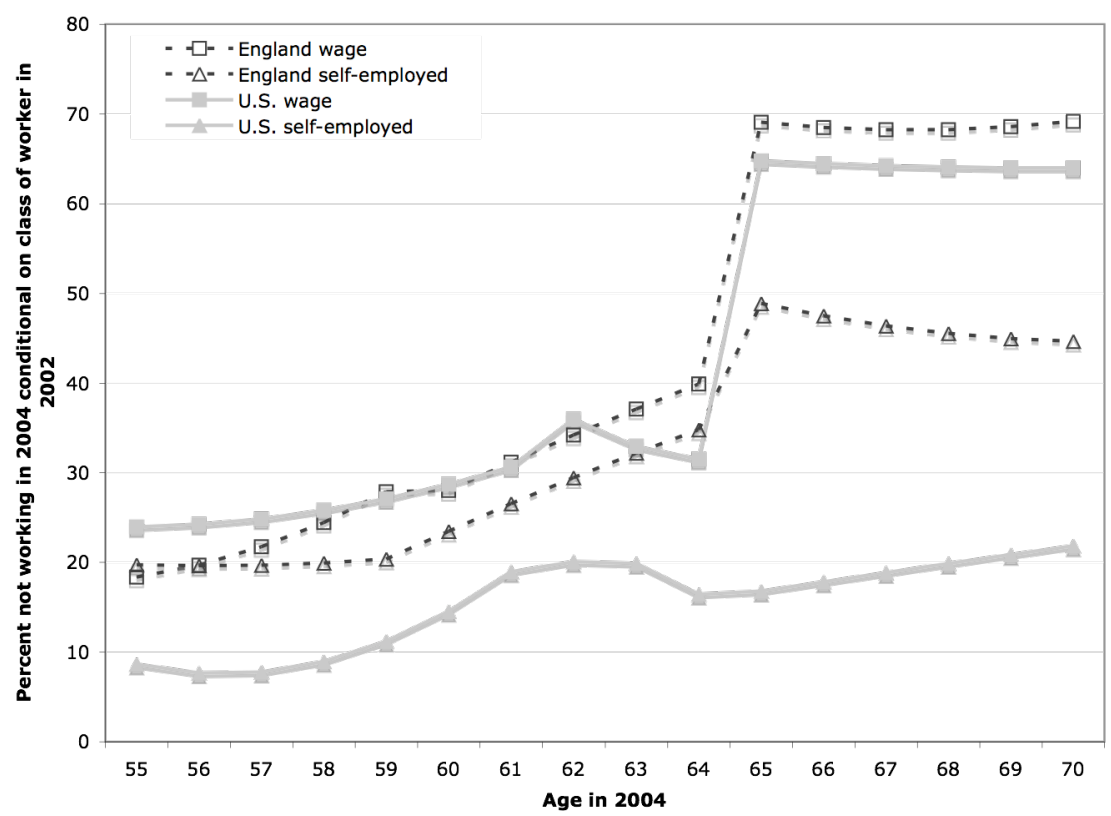

NOTE: Predicted probabilities based on regression results reported in Table 6 .

SOURCE: Authors' calculations using the 2002 and 2004 waves of HRS and ELSA 